\title{
Identification of the most potent acetylcholinesterase inhibitors from plants for possible treatment of Alzheimer's disease: a computational approach
}

Bishajit Sarkar ${ }^{1 *}$ (D, Sayka Alam ${ }^{1 \dagger}$, Tiluttoma Khan Rajib ${ }^{1+}$, Syed Sajidul Islam ${ }^{1+}$, Yusha Araf ${ }^{2}$ and Md. Asad Ullah ${ }^{1}$

\begin{abstract}
Background: Being one of the rapidly growing dementia type diseases in the world, Alzheimer's disease (AD) has gained much attention from researchers in the recent decades. Many hypotheses have been developed that describe different reasons for the development of AD. Among them, the cholinergic hypothesis depicts that the degradation of an important neurotransmitter, acetylcholine by the enzyme acetylcholinesterase (AChE), is responsible for the development of AD. Although, many anti-AChE drugs are already available in the market, their performance sometimes yields unexpected results. For this reason, research works are going on to find out potential anti-AChE agents both from natural and synthetic sources. In this study, 50 potential anti-AChE phytochemicals were analyzed using numerous tools of bioinformatics and in silico biology to find out the best possible anti-AChE agents among the selected 50 ligands through molecular docking, determination of the druglikeness properties, conducting the ADMET test, PASS and P450 site of metabolism prediction, and DFT calculations.

Result: The predictions of this study suggested that among the selected 50 ligands, bellidifolin, naringenin, apigenin, and coptisine were the 4 best compounds with quite similar and sound performance in most of the experiments.

Conclusion: In this study, bellidifolin, naringenin, apigenin, and coptisine were found to be the most effective agents for treating the AD targeting AChE. However, more in vivo and in vitro analyses are required to finally confirm the outcomes of this research.
\end{abstract}

Keywords: Alzheimer's disease, Acetylcholinesterase, Molecular docking, Phytochemicals, Druglikeness properties, ADMET, PASS prediction, Naringenin

\footnotetext{
* Correspondence: sarkarbishajit@gmail.com

${ }^{\dagger}$ The authors Sayka Alam, Tiluttoma Khan Rajib, and Syed Sajidul Islam have contributed equally to the work and jointly hold the second authorship. 'Department of Biotechnology and Genetic Engineering, Faculty of Biological Sciences, Jahangirnagar University, Dhaka, Bangladesh

Full list of author information is available at the end of the article
}

\section{Springer Open}

(c) The Author(s). 2021 Open Access This article is licensed under a Creative Commons Attribution 4.0 International License, which permits use, sharing, adaptation, distribution and reproduction in any medium or format, as long as you give appropriate credit to the original author(s) and the source, provide a link to the Creative Commons licence, and indicate if changes were made. The images or other third party material in this article are included in the article's Creative Commons licence, unless indicated otherwise in a credit line to the material. If material is not included in the article's Creative Commons licence and your intended use is not permitted by statutory regulation or exceeds the permitted use, you will need to obtain permission directly from the copyright holder. To view a copy of this licence, visit http://creativecommons.org/licenses/by/4.0/. 


\section{Background}

First described by Alois Alzheimer in 1907, Alzheimer's Disease (AD) has become one of the most prevalent dementia type diseases in the world which is increasing its numbers rapidly [1, 2]. Intellectual morbidity, psychomotor dysregulation, delusions, hallucinations etc., are some of the familiar symptoms of $\mathrm{AD}$ [3]. In the familial and congenital cases of $\mathrm{AD}$, genetic factors play critical roles [4]. Different hypotheses have been developed by the scientists that shed light on several reasons for $\mathrm{AD}$ onset and development. One of these hypotheses is the amyloid cascade hypothesis, which describes that the deposition of $\beta$-amyloid plaques in the brain is mainly responsible for the development of $\mathrm{AD}$ which is the result of abnormal processing of the amyloid precursor protein (APP) by the $\beta$-secretase enzyme. These plaques interfere with the normal functions of the brain [5]. On the other hand, another hypothesis called the oxidative stress hypothesis describes that because of the deposition of increased amounts of ions like iron, aluminium, and mercury, free radicals and reactive oxygen species (ROS) are generated very rapidly in the brain which are responsible for increased lipid peroxidation and protein and DNA oxidation. The stresses produced by these oxidation events lead the way for the AD onset [6]. There is another hypothesis of AD development which is known as the cholinergic hypothesis. According to this hypothesis, the loss of functions of the cholinergic neurons and thus the cholinergic signaling and neurotransmission in the brain maybe responsible for $\mathrm{AD}$ [7]. Table 1 lists the current status of therapeutic agents that are intended to or being used to alleviate the complications related to AD. This experiment was conducted focusing on the cholinergic hypothesis of $\mathrm{AD}$ development.

\section{The cholinergic hypothesis and the development of Alzheimer's disease}

The cholinergic hypothesis concerns with one of the major neurotransmitters, acetylcholine ( $\mathrm{ACh}$ ) which is regulated by two enzymes, acetylcholinesterase (AChE) and choline acetyltransferase (ChAT) [13]. ACh is involved in many important functions of the brain like learning and memory generation processes. It performs its functions through binding to two types of receptors, i.e., nicotinic ( $\alpha 7$ and $\alpha 4 \beta 2$ ) and muscarinic receptors (M1 muscarinic receptor). ACh is synthesized by the enzyme choline acetyltransferase (ChAT) which catalyzes the transfer of an acetyl group from acetyl coenzyme A (Ac-CoA) to choline (Ch) in the pre-synaptic neuron and thus synthesizes the ACh. Thereafter, the ACh is secreted by the pre-synaptic neuron into the synapse where it mediates its effects by binding to either the nicotinic receptor or the muscarinic receptor. To maintain the optimal concentrations of $\mathrm{ACh}$ required for proper functioning of the brain, another enzyme called acetylcholinesterase (AChE) is synthesized by a serine hydrolase enzyme which hydrolyzes $\mathrm{ACh}$ to acetate and $\mathrm{Ch}$. Then the $\mathrm{Ch}$ is again taken up by the pre-synaptic neuron for recycling and reusing. Thus, the balance of $\mathrm{ACh}$ is maintained in the normal brain. However, there is evidence that, in the brain of $\mathrm{AD}$ patients, the overexpression of $\mathrm{AChE}$ occurs. This phenomenon decreases the amount of $\mathrm{ACh}$ required for proper functioning of the brain which is why the neuron cells cannot operate properly and complications like brain damage as well as memory loss occur. These complications lead to the onset of AD development (Fig. 1) [14-18].

Donepezil and rivastigmine are two FDA-approved drugs that are currently used for mild to moderate $\mathrm{AD}$ treatment targeting the AChE enzyme. However, both of them have several side effects like nausea, diarrhea, anorexia, syncope, abdominal pain, and vomiting [19, 20]. Therefore, scientists are searching for more effective agents that can provide more efficacy than these drugs with much lesser side effects. Scientists have also focused on the natural resources for potential anti-AChE agents since the natural agents are generally much safer than synthetic chemicals. Galantamine is such a natural drug isolated from Galanthus woronowii which is also currently used for $\mathrm{AD}$ treatment alongside other approved chemical drugs. But since none of these drugs are found to be quite satisfactory to stop the progression or development of $\mathrm{AD}$, research is going on to find out new compounds from natural sources with anti-AChE properties [21-23].

Molecular docking is a widely accepted and used technique in drug $R \& D$ which reduces both time and costs of lead discovery processes. This method is also known as computational drug design which has already been used for designing over 50 novel drugs, and many of them have also gained FDA approval for marketing. By simulating the interaction between ligand and receptor in the computer software, the docking system assigns scoring functions to the bound ligands which reflect their binding affinity. The lower docking score represents the greater binding affinity and vice-versa [24, 25]. The current study was designed to predict the best ligands among 50 selected phytochemicals with potential anti-AChE activities based on the molecular docking analysis (Table 2). Thereafter, the pharmacodynamics and physicochemical characteristics of the best selected ligands were predicted by determining their druglikeness properties, conducting the ADMET test, PASS, and P450 site of metabolism prediction and DFT calculations.

\section{Methods}

Total 50 phytochemicals were selected as ligands in this study by reviewing numerous literatures along with their 
Table 1 Examples of AD treating agents, their mechanism of treatment, and their current status

\begin{tabular}{|c|c|c|c|c|c|}
\hline Hypothesis & Treating agents & $\begin{array}{l}\text { Mechanism of available } \\
\text { treatments }\end{array}$ & Current status & Remarks & References \\
\hline \multirow[t]{11}{*}{$\begin{array}{l}\text { Amyloid cascade } \\
\text { hypothesis }\end{array}$} & $\begin{array}{l}\text { Plasma exchange with } \\
\text { albumin } 1 \text { immunoglobulin }\end{array}$ & $\begin{array}{l}\text { Exchange of plasma to remove } \\
\text { the amyloid }\end{array}$ & $\begin{array}{l}\text { Phase-III clinical } \\
\text { trial }\end{array}$ & Ongoing research & {$[8,9]$} \\
\hline & ALZT-OP1a + ALZT-OP1b & $\begin{array}{l}\text { Alleviation of amyloid plaque } \\
\text { related neuroinflammation }\end{array}$ & $\begin{array}{l}\text { Phase-III clinical } \\
\text { trial }\end{array}$ & Ongoing research & \\
\hline & Elenbecestat & $\begin{array}{l}\text { Removal of amyloid by inhibiting } \\
\text { Beta-secretase } 1\end{array}$ & $\begin{array}{l}\text { Phase-III clinical } \\
\text { trial }\end{array}$ & Ongoing research & \\
\hline & Solanezumab & $\begin{array}{l}\text { Monoclonal antibodies targeting } \\
\text { amyloid plaque }\end{array}$ & Failed & Lack of efficacy & \\
\hline & Verubecestat & $\begin{array}{l}\text { Removal of amyloid by inhibiting } \\
\text { Beta-secretase } 1\end{array}$ & Failed & Lack of efficacy & \\
\hline & Lanabecestat & $\begin{array}{l}\text { Removal of amyloid by inhibiting } \\
\text { Beta-secretase } 1\end{array}$ & Failed & Lack of efficacy & \\
\hline & CAD106 & Vaccine-based therapy & Phase-II clinical trial & Ongoing research & \\
\hline & CNP520 & Inhibition of Beta-secretase 1 & Phase-II clinical trial & Ongoing research & \\
\hline & Crenezumab & $\begin{array}{l}\text { Monoclonal antibody targeting } \\
\text { amyloid plaque }\end{array}$ & $\begin{array}{l}\text { Ongoing } \\
\text { investigation }\end{array}$ & Ongoing research & \\
\hline & Neflamapimod & $\begin{array}{l}\text { Inhibition of inflammatory protein } \\
\text { p38a MAPK }\end{array}$ & $\begin{array}{l}\text { Ongoing } \\
\text { investigation }\end{array}$ & Ongoing research & \\
\hline & Aducanumab & $\begin{array}{l}\text { Monoclonal antibody targeting } \\
\text { amyloid plaque }\end{array}$ & $\begin{array}{l}\text { Phase-III clinical } \\
\text { trial }\end{array}$ & Ongoing research & \\
\hline \multirow[t]{7}{*}{$\begin{array}{l}\text { Oxidative stress } \\
\text { hypothesis }\end{array}$} & $\begin{array}{l}\text { Supplementation of Vitamin C } \\
\text { and Vitamin E }\end{array}$ & Antioxidant to neutralize the ROS & $\begin{array}{l}\text { Current } \\
\text { investigational } \\
\text { treatment }\end{array}$ & Ongoing study & {$[10,11]$} \\
\hline & Selenium & Antioxidant to neutralize the ROS & $\begin{array}{l}\text { Ongoing } \\
\text { investigation }\end{array}$ & Ongoing study & \\
\hline & Curcumin & Antioxidant to neutralize the ROS & $\begin{array}{l}\text { Current } \\
\text { investigational } \\
\text { treatment }\end{array}$ & Ongoing study & \\
\hline & Ginko biloba & Antioxidant to neutralize the ROS & Current treatment & $\begin{array}{l}\text { Most effective among the } \\
\text { available treatments }\end{array}$ & \\
\hline & Ebenone & Antioxidant to neutralize the ROS & $\begin{array}{l}\text { Ongoing } \\
\text { investigation }\end{array}$ & Ongoing study & \\
\hline & Estrogen & Antioxidant to neutralize the ROS & $\begin{array}{l}\text { Ongoing } \\
\text { investigation }\end{array}$ & Ongoing study & \\
\hline & Colostrinin & Antioxidant to neutralize the ROS & $\begin{array}{l}\text { Ongoing } \\
\text { investigation }\end{array}$ & Ongoing study & \\
\hline \multirow{4}{*}{$\begin{array}{l}\text { Cholinergic } \\
\text { hypothesis }\end{array}$} & Tacrine & Inhibition of acetylcholinesterase & Current treatment & Approved by FDA & [12] \\
\hline & Donepezil & Inhibition of acetylcholinesterase & Current treatment & Approved by FDA & \\
\hline & Galantamine & Inhibition of acetylcholinesterase & Current treatment & Approved by FDA & \\
\hline & Rivastigmine & Inhibition of acetylcholinesterase & Current treatment & Approved by FDA & \\
\hline
\end{tabular}

ROS reactive oxygen species, FDA Food and Drug Administration

IC50 values. On sequential docking experiment, four best ligands were selected as the best inhibitors of AChE. Thereafter, their different drug-like parameters were analysed in different experiments. Donepezil and galantamine were used as the positive controls in the study.

\section{Protein preparation and ramachandran plot generation} A three-dimensional structure of AChE (PDB ID: $1 \mathrm{ACJ})$ was downloaded in PDB format from protein data bank (www.rcsb.org). The proteins were then prepared and refined using the Protein Preparation Wizard in Maestro Schrödinger Suite 2018-4 [60]. During protein preparation, the bond orders were assigned and hydrogen molecules were added to heavy atoms as well as all the waters were deleted and the side chains were adjusted using Prime [61]. After that, the structure was optimized and minimized using force field OPLS_2005, which was conducted setting the maximum heavy atom RMSD (root-mean-square-deviation) to $30 \AA$ and any 


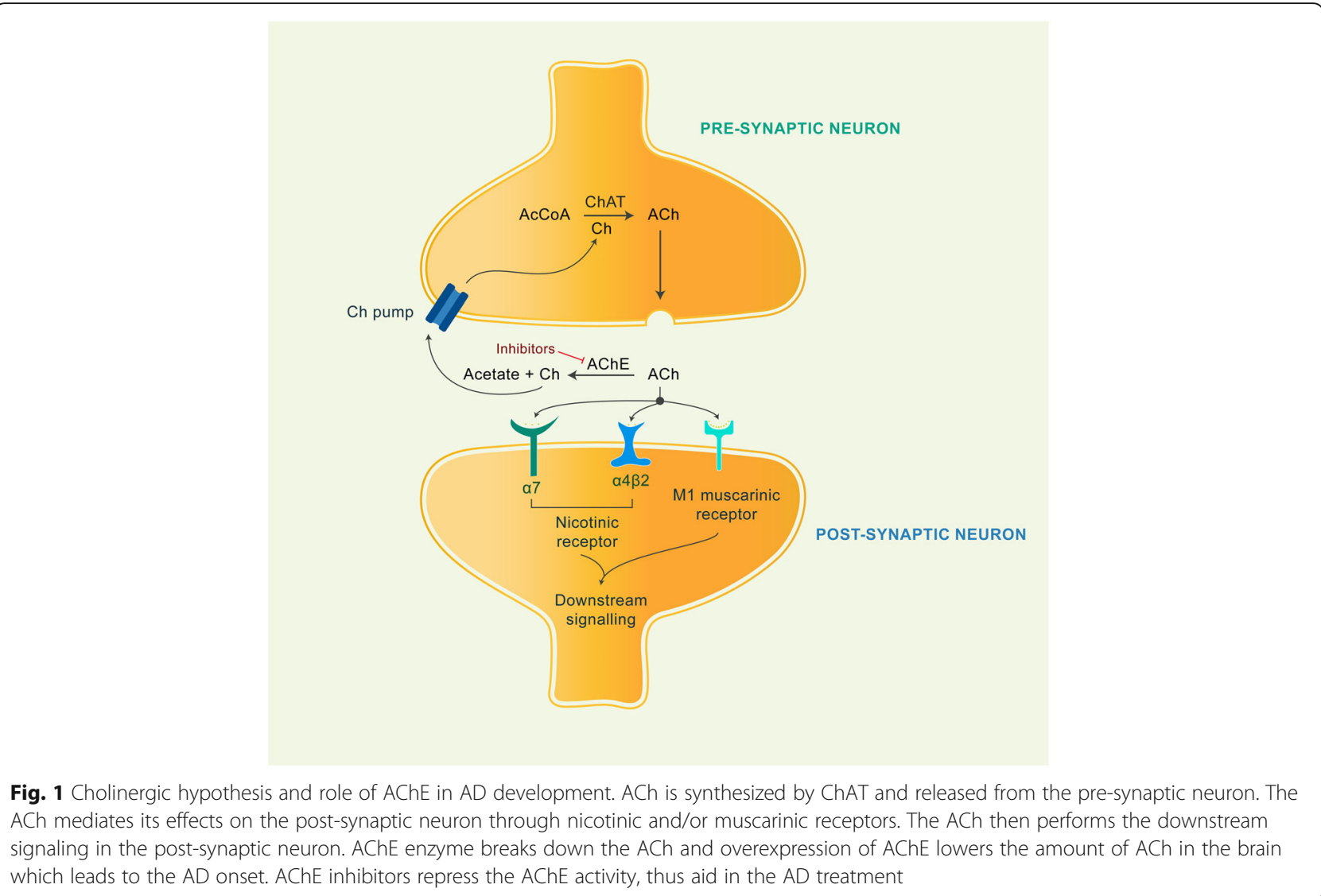

remaining water less than $3 \mathrm{H}$ - bonds to non-water was again deleted during the minimization step.

\section{Ligand preparation}

Three-dimensional structures of the 50 selected ligand molecules as well as the control were downloaded from PubChem database (www.pubchem.ncbi.nlm.nih.gov). These structures were prepared for docking using the LigPrep module of Maestro Schrödinger Suite [62]. Minimized 3D structures of ligands were generated by Epik 2.2 using OPLS_2005 force field and within pH 7.0 \pm 2.0 [63].

\section{Receptor grid generation}

Grid confines the active site of the receptor protein to a shortened specific area for the ligand to dock specifically. In glide, a grid was generated where the default Van der Waals radius scaling factor 1.0 and charge cutoff 0.25 was used. The grid was then subjected to OPLS_2005 force field. A cubic box was generated around the active site (reference ligand active site). Then, the grid box volume was adjusted to $14 \times 14 \times 14$ for docking test.
Glide standard precision (SP) and extra precision (XP) ligand docking, Prime MM-GBSA calculation and induced fit docking

SP and XP adaptable glide dockings were conducted using the Glide module in Maestro Schrödinger Suite [64]. The Van der Waals radius scaling factor and charge cutoff were kept at 0.80 and 0.15 , respectively, for all the ligand molecules. Final score was assigned by the module by analyzing the pose of docked ligand within the active site of the receptor.

After SP and XP ligand docking, the docked complexes were subjected to molecular mechanics-generalized born and surface area (MM_GBSA) rescoring with the help of Prime module of Maestro Schrödinger suite for further evaluation. This technique utilizes the docked complex and uses an implicit solvent that assigns more accurate scoring function and improves the overall freebinding affinity score upon the reprocessing of the complex. It combines OPLS molecular mechanics energies $\left(E_{M M}\right)$, surface generalized born solvation model for polar solvation $\left(\mathrm{G}_{\mathrm{SGB}}\right)$, and a nonpolar salvation term $\left(G_{N P}\right)$ for total free energy $\left(\Delta G_{\text {bind }}\right)$ calculation. The total free energy of binding was calculated by the following equation [65]: 
Table 2 List of the 50 anti-AChE ligands with their experimental IC50 values used in the experiment

\begin{tabular}{|c|c|c|c|c|c|}
\hline No & $\begin{array}{l}\text { Name of the } \\
\text { compound }\end{array}$ & $\begin{array}{l}\text { PubChem } \\
\text { CID }\end{array}$ & Source plant & IC50 value & References \\
\hline 01 & Geraniol & 637566 & Boesenbergia Pandurata & $200 \pm 0.21 \mu \mathrm{g} / \mathrm{ml}$ & {$[26,27]$} \\
\hline 02 & Bellidifolin & 5281623 & Swertia chirata & $18.47 \pm 0.47 \mu \mathrm{g} / \mathrm{ml}$ & {$[28]$} \\
\hline 03 & Mangiferin & 5281647 & S. chirata & $4.07 \pm 0.06 \mu \mathrm{g} / \mathrm{ml}$ & [28] \\
\hline 04 & Allocryptopine & 98570 & Chelidonium majus & $250 \pm 2.5 \mu \mathrm{M}$ & [29] \\
\hline 05 & Chelidonine & 197810 & Chelidonium majus & $26.8 \pm 1.2 \mu \mathrm{M}$ & [30] \\
\hline 06 & Isorhamnetin & 5281654 & Calendula officinalis & $24.18 \pm 0.74 \mu \mathrm{M}$ & [31] \\
\hline 07 & Quercetin & 5280343 & Calendula officinalis & $14.37 \pm 0.34 \mu \mathrm{M}$ & [30] \\
\hline 08 & Myricetin & 5281672 & Scabiosa arenaria & $190 \pm 0.41 \mu \mathrm{g} / \mathrm{ml}$ & {$[26,27]$} \\
\hline 09 & Ostruthin & 5281420 & Peucedanum ostruthium & - & [32] \\
\hline 10 & Ostruthol & 6441273 & Peucedanum ostruthium & - & [32] \\
\hline 11 & Corynoline & 177014 & Corydalis incisa & $30.6 \mu \mathrm{M} / \mathrm{mL}$ & [33] \\
\hline 12 & Imperatorin & 10212 & Peucedanum ostruthium, Angelica dahurica & $63.7 \mu \mathrm{M}$ & {$[32,33]$} \\
\hline 13 & Rupicoline & 633439 & Tabernaemontana australis & - & [34] \\
\hline 14 & Stylopine & 6770 & Corydalis crispa, Chelidonium majus & $114 \pm 2.9 \mu \mathrm{M}$ & {$[29,35]$} \\
\hline 15 & Scoulerine & 22955 & Corydalis dubia & $245 \mu \mathrm{M}$ & [35] \\
\hline 16 & Ochrobirine & 629543 & Corydalis crispa & - & [35] \\
\hline 17 & Estragole & 8815 & $\begin{array}{l}\text { O. basilicum, } O \text {. africanum, O.americanum, and } O \text {. } \\
\text { minimum }\end{array}$ & $0.337 \mu \mathrm{M}$ & [36] \\
\hline 18 & Naringenin & 932 & Citrus junos & 28.2 to $134.5 \mu \mathrm{M}$ & {$[37,38]$} \\
\hline 19 & Carvacrol & 10364 & Thymus vulgaris & $0.175 \mathrm{mM}$ & [39-41] \\
\hline 20 & Myrtenal & 61130 & Taxus baccata & $0.17 \pm 0.01 \mathrm{mM}$ & [41] \\
\hline 21 & Verbenone & 29025 & Taxus baccata & $2.66 \pm 1.04 \mathrm{mM}$ & [41] \\
\hline 22 & Cyclonataminol & 53316925 & Buxus natalensis & $23 \mu \mathrm{M}$ & {$[42,43]$} \\
\hline 23 & Buxaminol A & 53324855 & Buxus natalensis & $29.8 \pm 4.4 \mu \mathrm{M}$ & [43] \\
\hline 24 & Skimmianine & 6760 & Zanthoxylum nitidum & $\begin{array}{l}74.09 \pm 0.33 \mathrm{mg} / \\
\mathrm{mL}\end{array}$ & {$[44,45]$} \\
\hline 25 & Harmaline & 3564 & Peganum harmala & $8.4 \mu \mathrm{g} / \mathrm{mL}$ & [46] \\
\hline 26 & Harmine & 5280953 & Peganum harmala & $10.9 \mu \mathrm{g} / \mathrm{mL}$ & [46] \\
\hline 27 & Isoimperatorin & 68081 & Ruta graveolens, angelica dahurica & $74.6 \mu \mathrm{M}$ & {$[33,47]$} \\
\hline 28 & Xanthotoxin & 4114 & Ruta graveolens & $5.4 \times 10^{-5} \mathrm{M}$ & {$[47,48]$} \\
\hline 29 & Marmesin & 334704 & Ruta graveolens, angelica dahurica & $13.3 \mathrm{mM}$ & {$[46,49]$} \\
\hline 30. & 1,8-cineole & 2758 & Inula graveolens & $0.015 \mathrm{mg} / \mathrm{mL}$ & [50] \\
\hline 31 & Eugenol & 3314 & Inula graveolens & $0.48 \mathrm{mg} / \mathrm{mL}$ & [50] \\
\hline 32 & a-terpineol & 17100 & Inula graveolens & $1.3 \mathrm{mg} / \mathrm{mL}$ & [50] \\
\hline 33 & Apigenin & 5280443 & Sideritis cesarea & $7.72 \pm 0.15 \mu \mathrm{M}$ & {$[51,52]$} \\
\hline 34 & Linearol & 497896 & Sideritis congesta & $2.66 \mu \mathrm{g} / \mathrm{mL}$ & {$[52]$} \\
\hline 35 & Sidol & 194142985 & Sideritis congesta & $0.92 \mu \mathrm{g} / \mathrm{mL}$ & [52] \\
\hline 36 & Sideridiol & 12315541 & Sideritis congesta & $8.04 \mu \mathrm{g} / \mathrm{mL}$ & {$[52]$} \\
\hline 37 & Sudachitin & 12443122 & Micromeria cilicica & $65.2 \pm 0.82 \mu \mathrm{g} / \mathrm{mL}$ & [52] \\
\hline 38 & Ursolic acid & 64945 & Nepeta sorgerae & $39.19 \mu \mathrm{g} / \mathrm{mL}$ & {$[52]$} \\
\hline 39 & a-pinene & 6654 & Salvia potentillifolia & $0.022 \mathrm{mg} / \mathrm{mL}$ & {$[50,52]$} \\
\hline 40 & Liriodenine & 10144 & Beilschmiedia alloiophylla & $3.5 \pm 1.0 \mu \mathrm{M}$ & [53] \\
\hline 41 & Secoboldine & 10359075 & Beilschmiedia alloiophylla & $10.0 \pm 0.6 \mu \mathrm{M}$ & [54] \\
\hline 42 & Lauro-tetanine & 31415 & Beilschmiedia alloiophylla & $3.2 \pm 0.3 \mu \mathrm{M}$ & [55] \\
\hline
\end{tabular}


Table 2 List of the 50 anti-AChE ligands with their experimental IC50 values used in the experiment (Continued)

\begin{tabular}{|c|c|c|c|c|c|}
\hline No & $\begin{array}{l}\text { Name of the } \\
\text { compound }\end{array}$ & $\begin{array}{l}\text { PubChem } \\
\text { CID }\end{array}$ & Source plant & IC50 value & References \\
\hline 43 & Asimilobine & 160875 & Beilschmiedia alloiophylla & $8.7 \pm 1.5 \mu \mathrm{M}$ & [53] \\
\hline 44 & $\beta$-amyrone & 12306160 & Beilschmiedia alloiophylla & $8.4 \pm 2.0 \mu \mathrm{M}$ & [53] \\
\hline 45 & Berberine & 2353 & $\begin{array}{l}\text { Coptis chinensis, Berberis bealei and Phellodendron } \\
\text { chinense }\end{array}$ & $1.48 \pm 0.07 \mathrm{mg} / \mathrm{ml}$ & [54] \\
\hline 46 & Coptisine & 72322 & $\begin{array}{l}\text { Coptis chinensis, Berberis bealei and Phellodendron } \\
\text { chinense }\end{array}$ & $1.27 \pm 0.06 \mathrm{mg} / \mathrm{ml}$ & [54] \\
\hline 47 & Palmatine & 19009 & $\begin{array}{l}\text { Coptis chinensis, Berberis bealei and Phellodendron } \\
\text { chinense }\end{array}$ & $5.21 \pm 0.48 \mathrm{mg} / \mathrm{ml}$ & [54] \\
\hline 48 & Luteolin & 5280445 & Thymus vulgaris & $135 \pm 0.18 \mu \mathrm{g} / \mathrm{ml}$ & {$[26,55]$} \\
\hline 49 & Rutin & 5280805 & Micromeria cilicica, Fraxinus angustifolia & $149.0 \pm 6.6 \mu \mathrm{M}$ & {$[52,56]$} \\
\hline 50 & Kaempferol & 5280863 & Cleistocalyx operculatus & $30.4 \mu \mathrm{M}$ & {$[57]$} \\
\hline $\begin{array}{l}\text { Positive control } \\
1\end{array}$ & Donepezil & 3152 & NA & $6.7 \mathrm{nM}$ & [58] \\
\hline $\begin{array}{l}\text { Positive Control } \\
2\end{array}$ & Galantamine & 9651 & Galanthus woronowii & $0.35 \mu \mathrm{mol} / \mathrm{L}$ & [59] \\
\hline
\end{tabular}

NA data not available

$$
\begin{aligned}
\Delta G_{\text {bind }} & =G_{\text {complex }}-\left(G_{\text {protein }}-G_{\text {ligand }}\right), \text { where }, G \\
& =E_{M M}+G_{S G B}+G_{N P} .
\end{aligned}
$$

The agents with best results in the SP and XP docking were selected for the MM_GBSA and IFD studies.

Thereafter, to carry out the IFD of the selected ligand molecules from SP and XP docking, again OPLS_2005 force field was applied after generating grid around the co-crystallized ligand of the receptor, and this time, the best five ligands were docked rigidly. Receptor and ligand Van Der Waals screening was set at 0.70 and 0.50 , respectively, and residues within $2 \AA$ were refined to generate 2 best possible posses with extra precision. Four best performing ligands were selected according to their MM_GBSA score, IFD score, and $\mathrm{XP}_{\text {Gscore }}$. The 3D representations of the best pose interactions between the best four ligands and their respective receptors were obtained using Discovery Studio Visualizer [66]. At these stages, the docking parameters of the compounds under investigation were compared with the control

\section{Ligand-based drug likeness property and ADMET prediction}

The drug likeness properties of the 4 selected ligand molecules were analyzed using SWISSADME server (http://www.swissadme.ch/) [67]. After that, the ADME $\mathrm{T}$ for each of the ligand molecules was conducted using the online based server, ADMETlab (http://admet.scbdd. $\mathrm{com} /$ ) to predict various pharmacokinetic and pharmacodynamic properties $[68,69]$. The numeric and categorical values of the results generated by the ADME Tlab server were converted into qualitative values according to the documentation and explanation described in the ADMETlab server (http://admet.scbdd.com/ home/interpretation/) for the convenience of interpretation.

\section{PASS and SOM prediction}

The PASS (Prediction of Activity Spectra for Substances) prediction of the best four selected ligands were carried out by the PASS-Way2Drug server (http://www. pharmaexpert.ru/passonline/), using the canonical SMIL ES from PubChem server (https://pubchem.ncbi.nlm.nih. gov/) [70]. While carrying out PASS prediction, the $P_{a}$ (probability to be active) was kept greater than $70 \%$, since the $\mathrm{P}_{\mathrm{a}}>70 \%$ threshold generates highly reliable prediction [71]. In the PASS prediction study, 15 possible biological activities were predicted. The P450 Site of Metabolism (SOM) of the four best selected ligand molecules was determined by online tool, RSWebPredictor 1.0 (http://reccr.chem.rpi.edu/Software/ RS-WebPredictor/) [72]. Moreover, the LD50 value and toxicity class of the compounds were predicted using the ProTox-II server (http://tox.charite.de/protox_II/) [73].

\section{DFT calculations}

Minimized ligand structures obtained from LigPrep were used for DFT calculation using the Jaguar panel of Maestro Schrödinger Suite using Becke's threeparameter exchange potential and Lee-Yang-Parr correlation functional (B3LYP) theory with 6-31G* basis set [74-76]. Quantum chemical properties such as surface properties (MO, density, potential) and multipole moments were calculated along with HOMO (Highest Occupied Molecular Orbital) and LUMO (Lowest Unoccupied Molecular Orbital) energy. Then, the global frontier orbital was analyzed and hardness $(\boldsymbol{\eta})$ and softness $(\mathbf{S})$ of selected molecules were calculated using the 
following equation as per Parr and Pearson interpretation and Koopmans theorem [77, 78]. The DFT calculation was done for the 3 best ligand molecules.

$$
\begin{gathered}
\eta=(\mathrm{HOMO} \varepsilon-\mathrm{LUMO} \varepsilon) / 2 \\
S=1 / \eta
\end{gathered}
$$

\section{Result \\ Molecular docking study}

All the 50 selected ligands were docked successfully with their receptor protein, AchE. The ligand molecules that had the lowest binding energy were considered the best ligand molecules because lower binding energy or docking score represents higher binding affinity [79]. In the MM-GBSA study, the most negative $\triangle$ GBind score is also considered as the best $\Delta$ GBind score [80]. IFD study was conducted to determine the accurate binding mode and accuracy of active site geometry. The lowest values of IFD score and XP GScore represent the best results [81-84]. From the initial 50 ligands, the ligands that had both SP and XP scores of less than $-8.00 \mathrm{Kcal} / \mathrm{mol}$ were selected for MM_GBSA analysis and IFD study. Thirteen ligands were found to have both SP and XP scores less than $-8.00 \mathrm{Kcal} / \mathrm{mol}$ : bellidifolin, isoharmnetin, quercetin, myricetin, imperatorin, naringenin, harmaline, harmine, isoimperatorin, apigenin, coptisine, liriodenine, and scoulerine (Table 3). From these 13 ligands, 4 ligands were finally selected based on their lower scores in both MM_GBSA $\left(\Delta G_{\text {bind }}\right.$ score) and IFD studies (XP $G_{\text {score }}$ and IFD score), i.e., bellidifolin, naringenin, apigenin, and coptisine (Table 4). These four ligands were selected for further analysis to predict and determine their drug potentials. When compared to the two positive controls: donepezil and galantamine, it can be declared that these four compounds generated sound results in the molecular docking study.

\section{Binding mode of best ligands with respective targets}

The 3D representations as well as the interaction of different amino acids of the binding pocket of AChE with bellidifolin, naringenin, apigenin, and coptisine are illustrated in Fig. 2 and listed in Supplementary Table S1.

Bellidifolin generated an MM_GBSA score of - 55.23 $\mathrm{Kcal} / \mathrm{mol}$ when docked with acetylcholinesterase. It also generated the IFD score of $-1155.67 \mathrm{Kcal} / \mathrm{mol}$ and XP $\mathrm{G}_{\text {score }}$ of $-10.58 \mathrm{Kcal} / \mathrm{mol}$ against acetylcholinesterase. It formed two hydrogen bonds with glutamic acid 199 and histidine 440 at $2.18 \AA$ and $2.44 \AA$ distance apart, respectively. It was also reported to form multiple pi-pi stacked hydrophobic interactions with phenylalanine 330 $(\times 2)$ and tryptophan $84(\times 6)$ amino acid residues within the binding pocket of AChE.
Naringenin was docked with acetylcholinesterase where it generated the MM_GBSA score of - 42.02 $\mathrm{Kcal} / \mathrm{mol}$, IFD score of $-1156.52 \mathrm{Kcal} / \mathrm{mol}$, and XP $\mathrm{G}_{\text {score }}$ of $-12.24 \mathrm{Kcal} / \mathrm{mol}$. It formed four hydrogen bonds with histidine $440(\times 2)$, tyrosine 70 , and proline 86 at $1.69 \AA$, $2.38 \AA, 1.66 \AA$, and $2.99 \AA$ distance apart, respectively. It was also found to form multiple pi-pi stacked hydrophobic interactions with phenylalanine 330 and tryptophan $84(\times 2)$ amino acid residues within the binding pocket of AChE.

Apigenin was docked with acetylcholinesterase where it generated the MM_GBSA score of $-49.07 \mathrm{Kcal} / \mathrm{mol}$, IFD score of - $1154.41 \mathrm{Kcal} / \mathrm{mol}$, and $\mathrm{XP} \mathrm{G}_{\text {score }}$ of $11.78 \mathrm{Kcal} / \mathrm{mol}$. It formed six hydrogen bonds with glutamic acid $199(\times 2)$, glycine 117 , glycine 123 , serine 122 , and tyrosine 130 at $2.55 \AA, 2.26 \AA, 2.77 \AA, 2.90 \AA, 2.73 \AA$, and $2.76 \AA$ distance apart, respectively. It was also formed multiple pi-pi stacked hydrophobic interactions with tryptophan $84(\times 5)$, histidine 440 , and phenylalanine $330(\times 2)$ amino acid residues within the binding pocket of AChE.

Coptisine was docked with acetylcholinesterase, and it was found to generate the MM_GBSA score of - 59.41 $\mathrm{Kcal} / \mathrm{mol}$, IFD score of $-1160.39 \mathrm{Kcal} / \mathrm{mol}$, and XP $\mathrm{G}_{\text {score }}$ of $-16.24 \mathrm{Kcal} / \mathrm{mol}$. It formed six hydrogen bonds with histidine $440(\times 2)$, serine 122 , and glycine 117 at $2.21 \AA, 2.13 \AA, 3.01 \AA, 2.90 \AA$, and $2.53 \AA$ distance apart, respectively. It was also predicted to form multiple hydrophobic interactions with tryptophan $84(\times 7)$, tryptophan 432 , and phenylalanine $330(\times 3)$ amino acid residues within the binding pocket of AChE.

\section{Druglikeness properties}

The druglikeness property experiment was conducted for only the 4 best selected ligands: bellidifolin, naringenin, apigenin, and coptisine. All the 4 ligands were predicted to follow the Lipinski's rule of five. Moreover, bellidifolin was found to have the highest topological polar surface area (TPSA) value of $100.13 \AA^{2}$. Again, coptisine was predicted to have the highest molar refractivity of 87.95 as well as the highest concensus $\log P_{\mathrm{o} / \mathrm{w}}$ of 2.40 (Table 5). All the found compounds generated quite sound performance in the analysis when compared with the two positive controls, donepezil and galantamine.

\section{ADMET prediction}

The results of the ADMET test are summarized in Table 6 along with their comparison with donepezil and galantamine. All the four ligands performed quite similarly in the ADMET test. In the absorption section, all the ligands were predicted to be optimal Caco-2 permeable, whereas all of them were P-gp (P-glycoprotein) noninhibitors and P-gp non-substrates. In the distribution 
Table 3 The results of the SP and XP docking study of the selected ligands along with their respective glide energies

\begin{tabular}{|c|c|c|c|c|}
\hline No & $\begin{array}{l}\text { Name of the } \\
\text { compound }\end{array}$ & $\begin{array}{l}\text { Standard Precision (SP) Docking score/ } \\
\text { Binding energy (Kcal/mol) }\end{array}$ & $\begin{array}{l}\text { Extra Precision (XP) Docking score/ } \\
\text { Binding energy (Kcal/mol) }\end{array}$ & $\begin{array}{l}\text { Glide energy } \\
\text { (Kcal/mol) }\end{array}$ \\
\hline 01 & Coptisine & -11.12 & -15.98 & -48.31 \\
\hline 02 & Myricetin & -10.37 & -12.43 & -42.546 \\
\hline 03 & Quercetin & -9.82 & -11.22 & -44.872 \\
\hline 04 & Isorhamnetin & -9.66 & -10.31 & -47.76 \\
\hline 05 & Apigenin & -9.51 & -9.96 & -44.67 \\
\hline 06 & Naringenin & -9.36 & -10.22 & -53.39 \\
\hline 07 & Bellidifolin & -8.96 & -9.79 & -49.191 \\
\hline 08 & Harmine & -8.73 & -8.97 & -49.149 \\
\hline 09 & Imperatorin & -8.49 & -8.81 & -42.072 \\
\hline 10 & Harmaline & -8.34 & -9.07 & -38.62 \\
\hline 11 & Scoulerine & -8.33 & -8.14 & -41.25 \\
\hline 12 & Marmesin & -8.10 & -7.73 & -23.41 \\
\hline 13 & Isoimperatorin & -8.06 & -7.46 & -33.972 \\
\hline 14 & Liriodenine & -8.01 & -7.31 & -45.69 \\
\hline 15 & Carvacrol & -7.99 & -7.19 & -27.98 \\
\hline 16 & Xanthotoxin & -7.84 & -7.78 & -39.22 \\
\hline 17 & Corynoline & -7.69 & -7.11 & -39.95 \\
\hline 18 & Ostruthin & -7.59 & -6.90 & -48.51 \\
\hline 19 & $\beta$-amyrone & -7.41 & -7.63 & -40.65 \\
\hline 20 & Lauro-tetanine & -7.31 & -6.33 & -31.50 \\
\hline 21 & Ostruthol & -7.28 & -9.52 & -42.707 \\
\hline 22 & Sidol & -7.23 & -6.65 & -36.53 \\
\hline 23 & Berberine & -7.13 & -6.63 & -47.86 \\
\hline 24 & Buxaminol A & -6.84 & -7.44 & -24.70 \\
\hline 25 & Stylopine & -6.74 & -6.12 & -32.544 \\
\hline 26 & Ochrobirine & -6.74 & -7.87 & -28.776 \\
\hline 27 & Secoboldine & -6.71 & -8.48 & -33.87 \\
\hline 28 & Skimmianine & -6.62 & -6.13 & -40.65 \\
\hline 29 & Palmatine & -6.45 & -6.90 & -30.91 \\
\hline 30 & a-pinene & -6.33 & -8.09 & -30.32 \\
\hline 31 & Sudachitin & -6.31 & -8.26 & -21.28 \\
\hline 32 & Eugenol & -6.30 & -6.42 & -24.55 \\
\hline 33 & Kaempferol & -6.27 & -9.25 & -31.34 \\
\hline 34 & Myrtenal & -6.15 & -7.95 & -43.53 \\
\hline 35 & Cyclonataminol & -6.11 & -5.41 & -33.46 \\
\hline 36 & Rupicoline & -5.99 & -7.03 & -48.430 \\
\hline 37 & a-terpineol & -5.84 & -6.32 & -36.76 \\
\hline 38 & Estragole & -5.77 & -6.24 & -44.384 \\
\hline 39 & Luteolin & -5.74 & -6.87 & -28.76 \\
\hline 40 & Geraniol & -5.69 & -7.19 & -34.712 \\
\hline 41 & 1,8-cineole & -5.67 & -4.05 & -44.68 \\
\hline 42 & Asimilobine & -5.66 & -7.05 & -22.69 \\
\hline 43 & Rutin & -5.64 & -7.30 & -43.66 \\
\hline
\end{tabular}


Table 3 The results of the SP and XP docking study of the selected ligands along with their respective glide energies (Continued)

\begin{tabular}{lllll}
\hline No & $\begin{array}{l}\text { Name of the } \\
\text { compound }\end{array}$ & $\begin{array}{l}\text { Standard Precision (SP) Docking score/ } \\
\text { Binding energy (Kcal/mol) }\end{array}$ & $\begin{array}{l}\text { Extra Precision (XP) Docking score/ } \\
\text { Binding energy (Kcal/mol) }\end{array}$ & $\begin{array}{l}\text { Glide energy } \\
\text { (Kcal/mol) }\end{array}$ \\
\hline 44 & Sideridiol & -5.54 & -8.94 & -28.92 \\
45 & Ursolic acid & -5.40 & -6.95 & -34.12 \\
46 & Linearol & -5.24 & -6.56 & -36.59 \\
47 & Chelidonine & -5.15 & -5.89 & -40.963 \\
48 & Verbenone & -4.80 & -4.17 & -27.52 \\
49 & Mangiferin & -4.65 & -4.22 & -29.058 \\
50 & Allocryptopine & -4.39 & -2.66 & -32.638 \\
Positive & Donepezil & -7.34 & -9.10 & -43.91 \\
control 1 & & & & -41.29 \\
Positive & Galantamine & -6.15 & -8.21 & \\
Control 2 & & & & \\
\hline
\end{tabular}

section, apigenin showed relatively poor performance with no capacity to be blood-brain barrier (BBB) permeable. In the metabolism section, all of the ligands were predicted to be CYP450 1A2 inhibitor and only apigenin was found to be CYP450 1A2 non-substrate. However, all of them were CYP450 2C9 and CYP450 2C19 noninhibitors and bellidifolin and apigenin were substrates for CYP450 2C9. Moreover, only bellidifolin and coptisine were found to be substrates for CYP450 2C19 and CYP450 2D6. In the excretion section, coptisine was found to have the highest half-life of $1.8 \mathrm{~h}$. In the toxicity section, all the four ligands were found to be drug induced liver toxicity (DILI) positive and only bellidifolin was Ames positive as well as hERG non-blocker. Moreover, both naringenin and coptisine were found to have human hepatotoxicity. The performance of the 4 finally selected ligands was not very different from that of the two positive controls.

\section{PASS and P450 site of metabolism prediction}

The predicted LD50 value for bellidifolin, naringenin, apigenin, and coptisine were $4000 \mathrm{mg} / \mathrm{kg}, 2000 \mathrm{mg} / \mathrm{kg}$, $2500 \mathrm{mg} / \mathrm{kg}$, and $1000 \mathrm{mg} / \mathrm{kg}$, respectively. Moreover, both bellidifolin and apigenin were predicted to be in toxicity class 5 , whereas naringenin and coptisine were found to be in toxicity class 4 . The prediction of activity spectra for substances (PASS prediction) was conducted for the 4 ligands to identify 15 intended biological activities. The PASS prediction results of the 4 selected ligands along with the positive control donepezil are listed in Table 7. Coptisine did not show any of the activities; however, both bellidifolin and apigenin were

Table 4 The results of the MM_GBSA and IFD studies of the 13 ligands selected from the SP and XP docking studies along with the positive controls

\begin{tabular}{lllll}
\hline No & Name & MM_GBSA $\Delta \mathbf{G}_{\text {bind }}$ Score $(\mathbf{K c a l} / \mathbf{m o l})$ & XP $\mathbf{G}_{\text {score }}(\mathbf{K c a l} / \mathbf{m o l})$ & IFD score $($ Kcal/mol) \\
\hline 01 & Coptisine & -59.41 & -16.24 & -1160.39 \\
02 & Bellidifolin & -55.23 & -10.58 & -1155.67 \\
03 & Apigenin & -49.07 & -11.78 & -1154.41 \\
04 & Narigenin & -42.02 & -12.24 & -1156.52 \\
05 & Harmine & -41.20 & -10.24 & -1153.45 \\
06 & Imperatorin & -38.81 & -8.70 & -1152.22 \\
07 & Myricetin & -36.53 & -11.72 & -1149.29 \\
08 & Isoharmnetin & -35.29 & -9.69 & -1153.95 \\
09 & Scoulerine & -33.43 & -9.22 & -1140.92 \\
10 & Harmaline & -32.24 & -6.78 & -1159.54 \\
11 & Isoimperatorin & -32.96 & -7.54 & -1155.66 \\
12 & Quercetin & -30.54 & -8.01 & -1151.03 \\
13 & Liriodenine & -29.19 & -7.80 & -1152.97 \\
Positive control 1 & Donepezil & -47.06 & -8.21 & -1148.97 \\
Positive Control 2 & Galantamine & -40.92 & -7.40 & -1148.23 \\
\hline
\end{tabular}



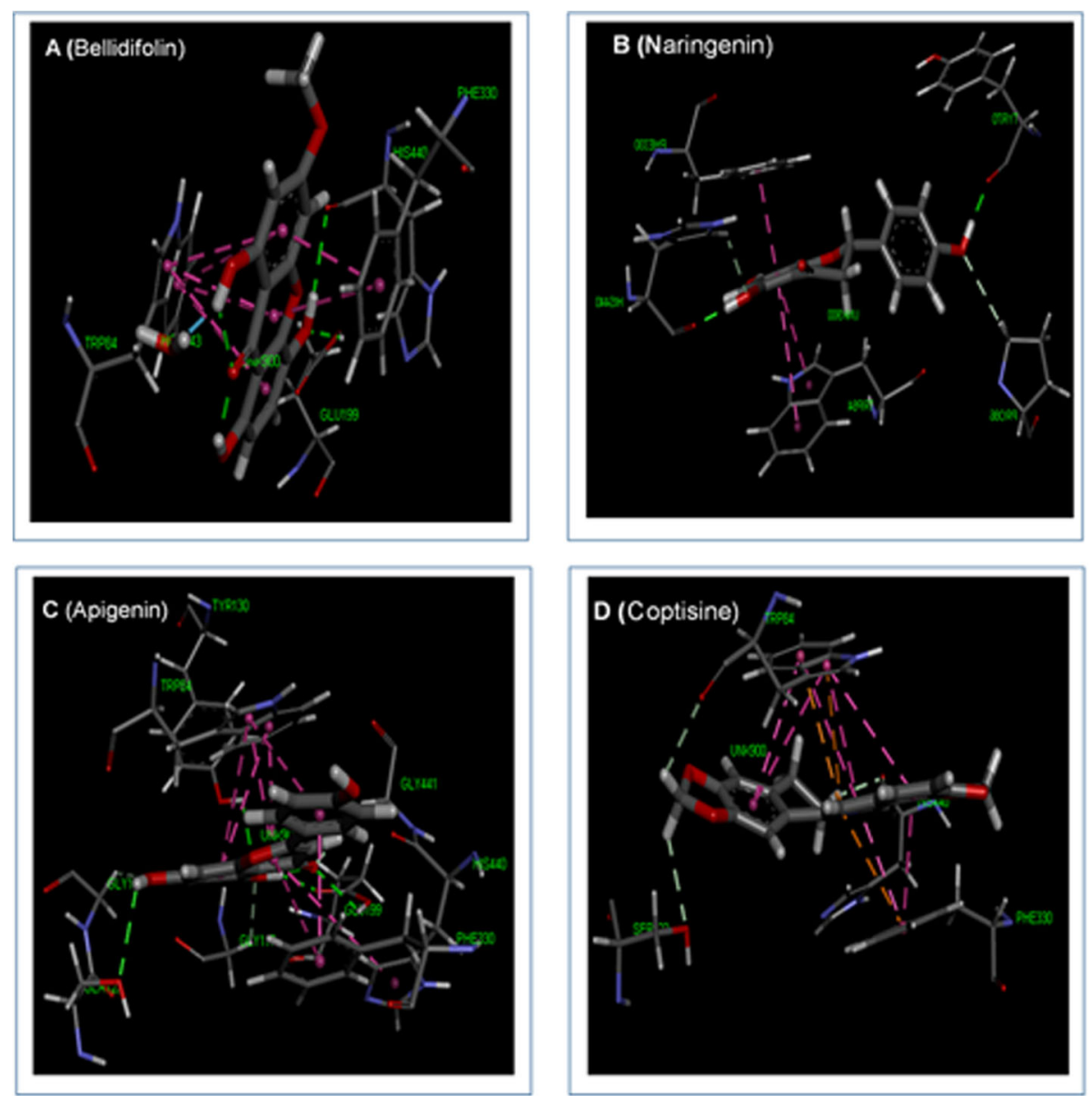

Fig. 2 Figure showing the various types of bonds and amino acids that take part in the interaction between the 4 best selected ligands (a bellidifolin, $\mathbf{b}$ naringenin, $\mathbf{c}$ apigenin, $\mathbf{d}$ coptisine) and their receptor, AChE. Interacting amino acid residues of target molecule are labeled in the diagram and dotted lines depict the interaction between the ligand and receptor. Green dotted lines—conventional bond; deep pink—Pi-Pi stacked bond; and orange-charge-charge interaction

Table 5 The druglikeness properties of the best 4 ligands and the positive controls

\begin{tabular}{llllllll}
\hline $\begin{array}{l}\text { Drug Likeness } \\
\text { Properties }\end{array}$ & Rules & Bellidifolin & Naringenin & Apigenin & Coptisine & $\begin{array}{l}\text { Donepezil (positive } \\
\text { control 1) }\end{array}$ & $\begin{array}{l}\text { Galantamine (positive } \\
\text { control 2) }\end{array}$ \\
\hline Lipinski's rule of five & - & Yes & Yes & Yes & Yes & Yes & Yes \\
Molecular weight & $<500$ & $\begin{array}{l}274.23 \mathrm{~g} / \\
\mathrm{mol}\end{array}$ & $\begin{array}{l}272.25 \mathrm{~g} / \\
\mathrm{mol}\end{array}$ & $\begin{array}{l}270.24 \mathrm{~g} / \\
\mathrm{mol}\end{array}$ & $\begin{array}{l}320.32 \mathrm{~g} / \\
\mathrm{mol}\end{array}$ & $379.49 \mathrm{~g} / \mathrm{mol}$ & $287.35 \mathrm{~g} / \mathrm{mol}$ \\
Concensus log $P_{\mathrm{o} / \mathrm{w}}$ & $\leq 5$ & 1.77 & 1.84 & 2.11 & 2.40 & 4.00 & 1.91 \\
Num. H-bond acceptors & $<10$ & 6 & 5 & 5 & 4 & 4 & 4 \\
Num. H-bond donors & $<5$ & 3 & 3 & 3 & 0 & 0 & 1 \\
Molar refractivity & $40-$ & 72.55 & 71.57 & 73.99 & 87.95 & 115.31 & 84.05 \\
No of rotatable bonds & $\leq 10$ & 1 & 1 & 1 & 0 & 6 & 1 \\
TPSA $\left(\AA^{2}\right)$ & - & $100.13 \AA^{2}$ & 71.57 & $90.90 \AA^{2}$ & $40.80 \AA^{2}$ & 38.77 & 41.93 \\
\hline
\end{tabular}


Table 6 The ADME/T test results of the best 4 ligand molecules along with the two positive controls

\begin{tabular}{|c|c|c|c|c|c|c|c|}
\hline Class & Properties & Bellidifolin & Naringenin & Apigenin & Coptisine & $\begin{array}{l}\text { Donepezil (positive } \\
\text { control 1) }\end{array}$ & $\begin{array}{l}\text { Galantamine (positive } \\
\text { control 2) }\end{array}$ \\
\hline \multirow[t]{4}{*}{ Absorption } & Caco-2 permeability & Optimal & Optimal & Optimal & Optimal & Optimal & Optimal \\
\hline & Pgp-inhibitor & $\begin{array}{l}\text { Non- } \\
\text { inhibitor }\end{array}$ & $\begin{array}{l}\text { Non- } \\
\text { inhibitor }\end{array}$ & $\begin{array}{l}\text { Non- } \\
\text { inhibitor }\end{array}$ & $\begin{array}{l}\text { Non- } \\
\text { inhibitor }\end{array}$ & Inhibitor & Non-inhibitor \\
\hline & Pgp-substrate & $\begin{array}{l}\text { Non- } \\
\text { substrate }\end{array}$ & $\begin{array}{l}\text { Non- } \\
\text { substrate }\end{array}$ & $\begin{array}{l}\text { Non- } \\
\text { substrate }\end{array}$ & $\begin{array}{l}\text { Non- } \\
\text { substrate }\end{array}$ & Non-substrate & Substrate \\
\hline & $\begin{array}{l}\text { Human Intestinal } \\
\text { Absorption (HIA) }\end{array}$ & $\begin{array}{l}\text { HIA } \\
\text { positive }\end{array}$ & $\begin{array}{l}\text { HIA } \\
\text { positive }\end{array}$ & $\begin{array}{l}\text { HIA } \\
\text { positive }\end{array}$ & $\begin{array}{l}\text { HIA } \\
\text { negative }\end{array}$ & HIA positive & HIA positive \\
\hline \multirow[t]{2}{*}{ Distribution } & Plasma Protein Binding & Moderate & Moderate & Optimal & Low & Optimal & Low \\
\hline & BBB (Blood-Brain Barrier) & $\begin{array}{l}\text { BBB } \\
\text { positive }\end{array}$ & $\begin{array}{l}\text { BBB } \\
\text { positive }\end{array}$ & $\begin{array}{l}\text { BBB } \\
\text { negative }\end{array}$ & $\begin{array}{l}\text { BBB } \\
\text { positive }\end{array}$ & BBB positive & BBB positive \\
\hline \multirow[t]{10}{*}{ Metabolism } & CYP450 1A2 inhibitor & Inhibitor & Inhibitor & Inhibitor & Inhibitor & Non-inhibitor & Non-inhibitor \\
\hline & CYP450 1A2 substrate & Substrate & Substrate & $\begin{array}{l}\text { Non- } \\
\text { substrate }\end{array}$ & Substrate & Non-substrate & Substrate \\
\hline & CYP450 3A4 inhibitor & $\begin{array}{l}\text { Non- } \\
\text { inhibitor }\end{array}$ & Inhibitor & Inhibitor & $\begin{array}{l}\text { Non- } \\
\text { inhibitor }\end{array}$ & Non-inhibitor & Non-inhibitor \\
\hline & CYP450 3A4 substrate & $\begin{array}{l}\text { Non- } \\
\text { substrate }\end{array}$ & $\begin{array}{l}\text { Non- } \\
\text { substrate }\end{array}$ & $\begin{array}{l}\text { Non- } \\
\text { substrate }\end{array}$ & Substrate & Substrate & Substrate \\
\hline & CYP450 2C9 inhibitor & $\begin{array}{l}\text { Non- } \\
\text { inhibitor }\end{array}$ & $\begin{array}{l}\text { Non- } \\
\text { inhibitor }\end{array}$ & $\begin{array}{l}\text { Non- } \\
\text { inhibitor }\end{array}$ & $\begin{array}{l}\text { Non- } \\
\text { inhibitor }\end{array}$ & Non-inhibitor & Non-inhibitor \\
\hline & CYP450 2C9 substrate & Substrate & $\begin{array}{l}\text { Non- } \\
\text { substrate }\end{array}$ & Substrate & $\begin{array}{l}\text { Non- } \\
\text { substrate }\end{array}$ & Non-substrate & Non-substrate \\
\hline & CYP450 2C19 inhibitor & $\begin{array}{l}\text { Non- } \\
\text { inhibitor }\end{array}$ & $\begin{array}{l}\text { Non- } \\
\text { inhibitor }\end{array}$ & $\begin{array}{l}\text { Non- } \\
\text { inhibitor }\end{array}$ & $\begin{array}{l}\text { Non- } \\
\text { inhibitor }\end{array}$ & Non-inhibitor & Non-inhibitor \\
\hline & CYP450 2C19 substrate & Substrate & $\begin{array}{l}\text { Non- } \\
\text { substrate }\end{array}$ & $\begin{array}{l}\text { Non- } \\
\text { substrate }\end{array}$ & Substrate & Substrate & Non-substrate \\
\hline & CYP450 2D6 inhibitor & $\begin{array}{l}\text { Non- } \\
\text { inhibitor }\end{array}$ & $\begin{array}{l}\text { Non- } \\
\text { inhibitor }\end{array}$ & Inhibitor & Inhibitor & Inhibitor & Inhibitor \\
\hline & CYP450 2D6 substrate & Substrate & $\begin{array}{l}\text { Non- } \\
\text { substrate }\end{array}$ & $\begin{array}{l}\text { Non- } \\
\text { substrate }\end{array}$ & Substrate & Substrate & Substrate \\
\hline Excretion & $\mathrm{T}_{1 / 2}(\mathrm{~h})$ & 1.0 & 0.9 & 1.3 & 1.8 & 1.6 & 1.7 \\
\hline \multirow[t]{4}{*}{ Toxicity } & hERG (hERG Blockers) & $\begin{array}{l}\text { Non- } \\
\text { blocker }\end{array}$ & Blocker & Blocker & Blocker & hERG positive & Non-blocker \\
\hline & $\begin{array}{l}\text { H-HT (Human } \\
\text { Hepatotoxicity) }\end{array}$ & $\begin{array}{l}\text { HHT } \\
\text { positive }\end{array}$ & $\begin{array}{l}\text { HHT } \\
\text { negative }\end{array}$ & $\begin{array}{l}\text { HHT } \\
\text { positive }\end{array}$ & $\begin{array}{l}\mathrm{HHT} \\
\text { negative }\end{array}$ & HHT positive & HHT positive \\
\hline & $\begin{array}{l}\text { Ames (Ames } \\
\text { Mutagenicity) }\end{array}$ & $\begin{array}{l}\text { Ames } \\
\text { positive }\end{array}$ & $\begin{array}{l}\text { Ames } \\
\text { negative }\end{array}$ & $\begin{array}{l}\text { Ames } \\
\text { negative }\end{array}$ & $\begin{array}{l}\text { Ames } \\
\text { negative }\end{array}$ & Ames negative & Ames negative \\
\hline & $\begin{array}{l}\text { DILI (Drug Induced Liver } \\
\text { Injury) }\end{array}$ & $\begin{array}{l}\text { DILI } \\
\text { positive }\end{array}$ & $\begin{array}{l}\text { DILI } \\
\text { positive }\end{array}$ & $\begin{array}{l}\text { DILI } \\
\text { positive }\end{array}$ & $\begin{array}{l}\text { DILI } \\
\text { positive }\end{array}$ & DILI negative & DILI negative \\
\hline
\end{tabular}

predicted to have 14 activities each. Naringenin showed all the 15 intended biological activities. On the other hand, the possible sites of metabolism (SOMs) by CYPs 1A2, 2A6, 2B6, 2C19, 2C8, 2C9, 2D6, 2E1, and 3A4 of bellidifolin, naringenin, apigenin, and coptisine were also determined, and the possible SOMs by these isoforms are indicated by circles on the chemical structure of the molecule [72] (Table 8). In both PASS and P450 SOM prediction, all the 4 compounds showed quite satisfactory performance which is comparable to the positive controls, donepezil and galantamine.

\section{Analysis of frontier's orbitals}

In the analysis of Frontier's orbitals, the DFT calculations were performed. The results of the DFT calculations are listed in Table 9. Coptisine showed the lowest gap energy of $0.047 \mathrm{eV}$ as well as the highest dipole moment of 6.459 debye. On the other hand, apigenin generated the highest gap energy of $0.130 \mathrm{eV}$ and the second highest dipole moment of 2.163 debye. The order of dipole moments of these 4 compounds were, bellidifolin < apigenin < naringenin $<$ coptisine. Comparing with the positive controls, it can be declared that all the four compounds showed sound results in the DFT calculations (Fig. 3). 
Table 7 The PASS prediction results showing the biological activities of the best 4 ligands and the positive controls

\begin{tabular}{|c|c|c|c|c|c|c|c|c|c|c|c|c|c|}
\hline \multirow[t]{4}{*}{ SI } & \multirow[t]{4}{*}{ Biological activities } & \multicolumn{2}{|c|}{ Bellidifolin } & \multicolumn{2}{|c|}{ Naringenin } & \multicolumn{2}{|c|}{ Apigenin } & \multicolumn{2}{|c|}{ Coptisine } & \multicolumn{2}{|c|}{$\begin{array}{l}\text { Donepezil } \\
\text { (positive } \\
\text { control 1) }\end{array}$} & \multicolumn{2}{|c|}{$\begin{array}{l}\text { Galantamine } \\
\text { (positive control } \\
\text { 2) }\end{array}$} \\
\hline & & \multicolumn{2}{|c|}{$\begin{array}{l}\text { Predicted LD50: } \\
4000 \mathrm{mg} / \mathrm{kg}\end{array}$} & \multicolumn{2}{|c|}{$\begin{array}{l}\text { Predicted LD50: } \\
2000 \mathrm{mg} / \mathrm{kg}\end{array}$} & \multicolumn{2}{|c|}{$\begin{array}{l}\text { Predicted LD50: } \\
2500 \mathrm{mg} / \mathrm{kg}\end{array}$} & \multicolumn{2}{|c|}{$\begin{array}{l}\text { Predicted } \\
\text { LD50: } 1000 \\
\mathrm{mg} / \mathrm{kg}\end{array}$} & \multicolumn{2}{|c|}{$\begin{array}{l}\text { Predicted LD50: } \\
1500 \mathrm{mg} / \mathrm{kg}\end{array}$} & \multicolumn{2}{|c|}{$\begin{array}{l}\text { Predicted LD50: } \\
2000 \mathrm{mg} / \mathrm{kg}\end{array}$} \\
\hline & & \multicolumn{2}{|c|}{ Toxicity class: 5} & \multicolumn{2}{|c|}{ Toxicity class: 4} & \multicolumn{2}{|c|}{ Toxicity class: 5} & \multicolumn{2}{|c|}{$\begin{array}{l}\text { Toxicity class: } \\
\mathbf{4}\end{array}$} & \multicolumn{2}{|c|}{ Toxicity class: 4} & \multicolumn{2}{|c|}{ Toxicity class: 4} \\
\hline & & $\mathrm{Pa}$ & $\mathrm{Pi}$ & $\mathrm{Pa}$ & $\mathrm{Pi}$ & $\mathrm{Pa}$ & $\mathrm{Pi}$ & $\mathrm{Pa}$ & $\mathrm{Pi}$ & $\mathrm{Pa}$ & $\mathrm{Pi}$ & $\mathrm{Pa}$ & $\mathrm{Pi}$ \\
\hline 01 & Antioxidant & - & - & 0.794 & 0.003 & 0,732 & 0,004 & - & - & 0.893 & 0.003 & 0.781 & 0.010 \\
\hline 02 & Membrane integrity agonist & 0.956 & 0.003 & 0.964 & 0.003 & 0.967 & 0.002 & - & - & 0.768 & 0.017 & 0.813 & 0.005 \\
\hline 03 & Antineoplastic & 0.742 & 0.019 & 0.751 & 0.018 & 0.774 & 0.015 & - & - & 0.823 & 0.005 & 0.956 & 0.002 \\
\hline 04 & Antimutagenic & 0.891 & 0.002 & 0.857 & 0.003 & 0.921 & 0.002 & - & - & 0.799 & 0.009 & 0.942 & 0.002 \\
\hline 05 & Mucomembranous protector & 0.710 & 0.052 & 0.844 & 0.010 & 0.797 & 0.019 & - & - & 0.773 & 0.011 & 0.764 & 0.014 \\
\hline 06 & Membrane integrity agonist & 0.754 & 0.010 & 0.924 & 0.003 & 0.967 & 0.002 & - & - & 0.834 & 0.004 & 0.720 & 0.015 \\
\hline 07 & TP53 expression enhancer & 0.853 & 0.007 & 0.822 & 0.009 & 0.873 & 0.006 & - & - & 0.920 & 0.002 & 0.798 & 0.008 \\
\hline 08 & Lipid peroxidase inhibitor & 0.755 & 0.004 & 0.815 & 0.003 & - & - & - & - & 0.875 & 0.009 & 0.909 & 0.005 \\
\hline 09 & HIF1A expression inhibitor & 0.937 & 0.004 & 0.911 & 0.005 & 0.911 & 0.005 & - & - & 0.751 & 0.019 & 0.866 & 0.009 \\
\hline 10 & APOA1 expression enhancer & 0.702 & 0.005 & 0.836 & 0.003 & 0.826 & 0.003 & - & - & 0.918 & 0.002 & 0.978 & 0.001 \\
\hline 11 & Free radical scavenger & 0.719 & 0.004 & 0.769 & 0.003 & 0.719 & 0.004 & - & - & 0.911 & 0.005 & 0.782 & 0.010 \\
\hline 12 & Peroxidase inhibitor & 0.908 & 0.003 & 0.818 & 0.004 & 0.924 & 0.002 & - & - & 0.912 & 0.008 & 0.930 & 0.003 \\
\hline 13 & Vasoprotector & 0.758 & 0.007 & 0.707 & 0.010 & 0.891 & 0.003 & - & - & 0.711 & 0.022 & 0.748 & 0.013 \\
\hline 14 & Histidine kinase inhibitor & 0.889 & 0.002 & 0.892 & 0.002 & 0.918 & 0.002 & - & - & 0.931 & 0.003 & 0.814 & 0.011 \\
\hline 15 & Apoptosis agonist & 0.833 & 0.006 & 0.709 & 0.014 & 0.847 & 0.005 & & - & 0.891 & 0.006 & 0.951 & 0.001 \\
\hline
\end{tabular}

\section{Discussion}

Molecular docking is an effective strategy in computer-aided drug designing which works on some specific algorithms and assigns affinity scores depending on the poses of the ligands inside the binding pocket of a target. In molecular docking, the lowest docking score corresponds to the highest affinity which reflects that the complex remains more time in contact with good stability $[85,86]$.

In this study, 50 compounds that were proven to have anti-AChE properties were selected by literature reviewing. Initially, from these 50 compounds, 13 compounds were selected based on their SP and XP docking scores (compounds having both SP and XP docking scores over - $8.0 \mathrm{Kcal} / \mathrm{mol}$ ). When compared with the positive controls, donepezil and galantamine, all the compounds were found to have relatively good results in molecular docking analysis. The 13 ligands selected from the initial docking analysis had predicted results better than donepezil. Later, from these 13 compounds, according to the MM_GBSA and IFD scores, 4 compounds, i.e., bellidifolin, naringenin, apigenin, and coptisine, were selected as final ligands for further analysis. These final compounds were also predicted to have better results than donepezil and galantamine in the MM_GBSA and IFD studies.
AChE possesses several notable amino acids in its active-site gorge, i.e., serine 200, glutamic acid 327, histidine 440, tryptophan 279 , tyrosine 121 , phenylalanine 330 , and tryptophan 84 . All the 4 finally selected ligands were found to form potential hydrogen and hydrophobic interactions with histidine 440, phenylalanine 330, and tryptophan 84 within the active site of AChE. Since hydrogen and hydrophobic interactions are important for strengthening the receptor-ligand interactions, it can be declared that these ligands might be able to effectively inhibit the AChE enzyme at its active site [87, 88].

The prediction of druglikeness properties facilitates the drug development processes. The molecular weight and TPSA are two important characteristics of a drug that affect its permeability through the biological barriers. Higher molecular weight and TPSA represent lower permeability of the drug molecule and vice-versa. Again, the lipophilicity (expressed as $\log \mathrm{P}$ ) influences the absorption of the drug molecule in the body and the higher $\log \mathrm{P}$ of a drug represents its lower absorption in the body. The capability of a drug molecule to cross the cell membrane is also influenced by the number of hydrogen bond acceptors and donors beyond the acceptable range. Moreover, the number of rotatable bonds (acceptable range is less than 10) also influences the 
Table 8 The P450 site of metabolism prediction of the best four ligand molecules and the positive controls

\begin{tabular}{|c|c|c|c|c|}
\hline $\begin{array}{c}\text { Names } \\
\text { of P450 } \\
\text { enzyme } \\
\text { s }\end{array}$ \\
\hline 1A2
\end{tabular}


Table 9 The results of the DFT calculations of the selected best 4 ligands and the positive controls

\begin{tabular}{lllllll}
\hline Compound name & $\begin{array}{l}\text { HOMO energy } \\
(\mathbf{e V})\end{array}$ & $\begin{array}{l}\text { LUMO energy } \\
(\mathrm{eV})\end{array}$ & $\begin{array}{l}\text { Gap } \\
(\mathrm{eV})\end{array}$ & $\begin{array}{l}\text { Hardness }(\mathbf{n}) \\
(\mathrm{eV})\end{array}$ & $\begin{array}{l}\text { Softness (S) } \\
(\mathrm{eV})\end{array}$ & $\begin{array}{l}\text { Dipole moment } \\
(\mathbf{D e b y e})\end{array}$ \\
\hline Bellidifolin & -0.015 & 0.101 & 0.116 & 0.058 & 17.241 & 1.630 \\
Naringenin & -0.005 & 0.094 & 0.099 & 0.049 & 20.408 & 2.278 \\
Apigenin & -0.048 & 0.082 & 0.130 & 0.065 & 15.385 & 2.163 \\
Coptisine & -0.134 & -0.087 & 0.047 & 0.023 & 21.276 & 6.459 \\
Donepezil (positive control 1) & -0.028 & 0.076 & 0.104 & 0.032 & 18.560 & 2.398 \\
Galantamine (positive control 2) & -0.022 & 0.081 & 0.103 & 0.047 & 16.141 & 3.041 \\
\hline
\end{tabular}

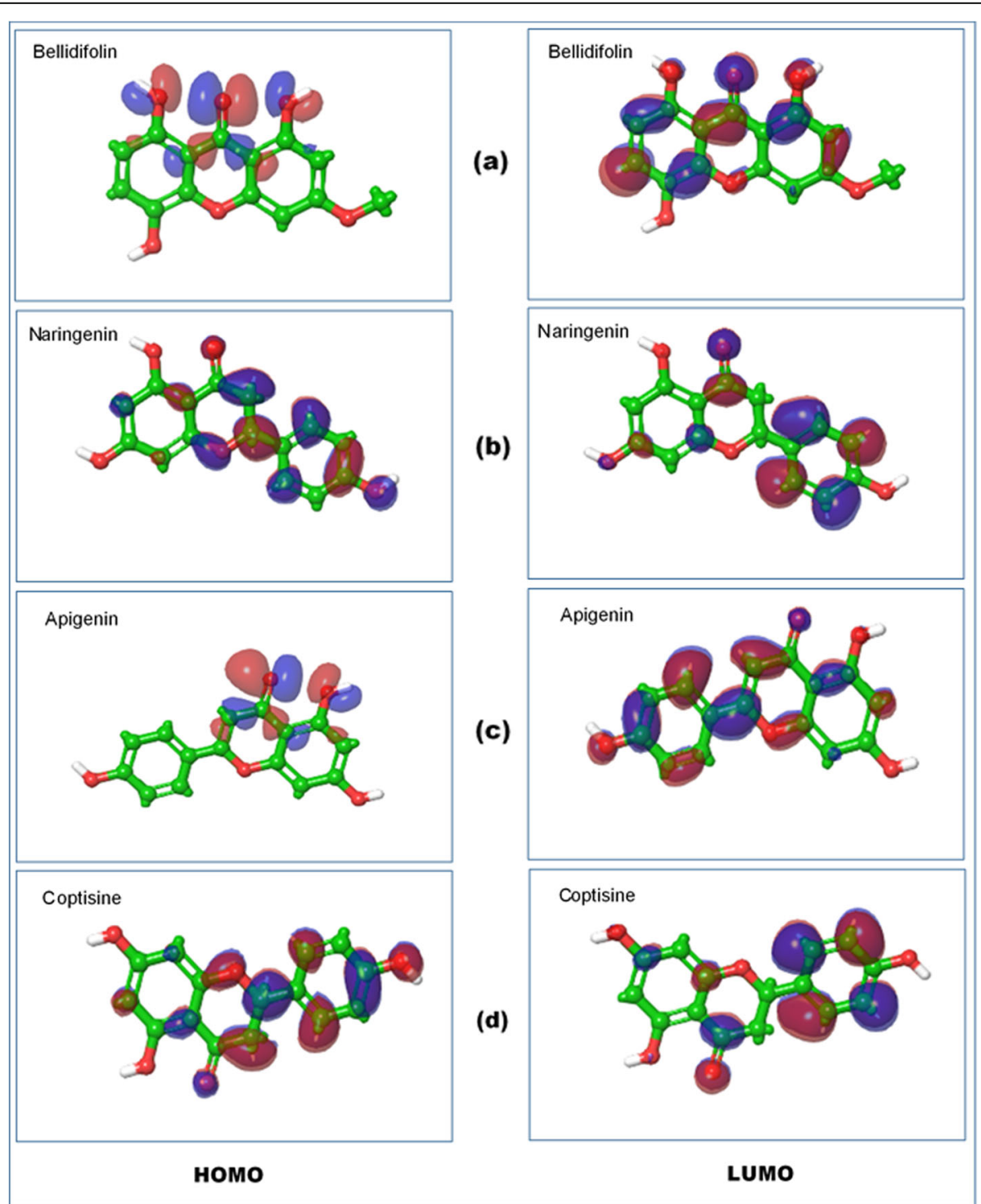

Fig. 3 The results of HOMO and LUMO studies; a bellidifolin, $\mathbf{b}$ naringenin, $\mathbf{c}$ apigenin, and $\mathbf{d}$ coptisine 
druglikeness properties of a drug. Furthermore, the Lipinski's rule of five demonstrates that a successful drug should have properties within the acceptable range of the five Lipinski's rules, i.e., molecular weight $\leq 500$, number of hydrogen bond acceptors $\leq 10$, number of hydrogen bond donors $\leq 5$, molar refractivity from 40 to 130 , and lipophilicity (expressed as $\log \mathrm{P}$ ) $\leq 5$ [89-92]. All the 4 selected ligands were found to follow the five Lipinski's rules of druglikeness properties. All of them showed quite good results in the druglikeness property experiment and for this reason, and all of them were considered as potential drug candidates.

ADMET prediction of a candidate drug aids in determining the pharmacological and pharmacodynamic properties of the drug molecule within a biological system. For this reason, the ADMET properties are important determinants for the success of a drug development process. BBB permeability is the most important characteristic of the drugs which primarily target the brain cells. Again, the transportation of drugs is influenced by the P-glycoprotein (P-gp) in the cell membrane; therefore, inhibition of this protein severely affects the drug transport. Moreover, if a drug is found to be permeable in the Caco-2 cell line, then that particular drug is considered to be absorbed well in the intestine. Orally absorbed drugs travel through the blood circulation and deposit in the liver where they are metabolized by group of enzymes of the Cytochrome P450 family and later excreted as bile or urine. Therefore, inhibition of any of these enzymes affects the metabolism and biodegradation of the drugs $[93,94]$. Furthermore, if a drug is found to be a substrate for one or more CYP450 enzyme or enzymes, then that drug is considered to be metabolized well by the respective CYP450 enzyme or enzymes [95]. A drug's pharmacodynamic properties depend on the degree of its binding with the plasma protein. A drug can pass through the cell layers if it binds to the plasma proteins less efficiently and vice versa [96]. Human intestinal absorption (HIA) is another crucial determinant for the orally administered drugs [97-99]. The half-life of a drug describes that the greater the half-life, the longer it would stay in the body and the greater its potentiality [100-102].

Furthermore, HERG is a $\mathrm{K}+$ channel which is found in the heart muscle. Blocking the hERG channel or signaling may cause cardiac arrhythmia leading to death $[103,104]$. On the other hand, human hepatotoxicity (H-HT) refers to any type of acute liver injury which may lead to organ failure and death $[105,106]$. The Ames test is a mutagenicity assay that is used to detect the potential mutagenic chemicals [107]. Drug induced liver injury (DILI) reflects the injuries in the liver that are caused by administration of drugs [108]. Bellidifolin, naringenin, and coptisine showed quite similar and sound performance in the
AMDET prediction. However, apigenin was found to be BBB impermeable and also a good binder to the plasma membrane, which could affect its biodistribution throughout the body as a potential inhibitor of AChE. As a consequence, the performance of apigenin in ADMET test was declared to be non-satisfactory.

Prediction of Activity Spectra for Substances or PASS prediction is a process of determining the biological activities of drug candidates or drug-like molecules. The PASS prediction estimates biological activities by predicting two potential probabilities: $\mathrm{Pa}$, which represents the probability of a compound to be active and $\mathrm{Pi}$, which represents the probability of a compound to be inactive. By predicting these two probabilities, the PASS prediction determines potential biological activities of a drug-like molecule. The Pa value of greater than 0.7 represents the greater probability of exhibiting the activity of a substance in an experiment. The $\mathrm{Pa}>70 \%$ threshold corresponds to a highly reliable prediction, while $\mathrm{Pa}>0.5$ gives quite reliable prediction and the $\mathrm{Pa}>0.3$ threshold describes that a compound is less likely to have the desired activity [70, 71, 109]. Most of the intended activities (13 activities) were common between bellidifolin, naringenin, and apigenin, for example, antineoplastic, antimutagenic, membrane integrity agonist, HIF1A expression inhibitor, and apoptosis agonist (Table 8).

The toxicity classes of the 4 compounds were determined by the ProTox-II server (http://tox.charite.de/ protox_II/index.php?site=compound_input), which predicts the toxicity of a compound and then classifies the compound into a toxicity class that ranges from 1 to 6 . To classify the compounds into toxicity classes, the server uses the Globally Harmonized System of Classification and Labelling of Chemicals (GHS). According this system, since both bellidifolin and apigenin had toxicity class 4, they would be harmful if swallowed. Again with the toxicity class of 5, both naringenin and coptisine might be harmful if swallowed $[73,110]$. Both the positive controls, donepezil and galantamine were found to have the toxicity class of 4 .

The cytochrome P450 or CYP450 represents a family of 57 isoforms of the heme-containing P450 enzymes. This enzyme family is one of the most important enzyme family for proper metabolism within the human body, which is responsible for catalyzing the phase-I metabolism of about $90 \%$ of all the marketed drugs. They also convert the lipophilic drugs or compounds to more polar, hydrophilic substances. Among these 57 isoforms of the CYP450 enzymes, 9 isoforms are most important for biological activities, i.e., CYPs 1A2, 2A6, 2B6, 2C19, 2C8, 2C9, 2D6, 2E1, and 3A4 [111, 112]. When the P450 SOMs of the 4 best selected ligands: bellidifolin, naringenin, apigenin, and coptisine were predicted, all of them showed potential SOMs where these 9 isoforms of 
Table 10 Overall comparison of the main features of bellidifolin, naringenin, apigenin, and coptisine as potential drugs to treat AD according to the study along with the 2 positive controls from comparison. All the compounds are ranked (excellent, good, and poor) based on their performance in every aspect

\begin{tabular}{|c|c|c|c|c|c|c|c|}
\hline Features & Bellidifolin & Naringenin & Apigenin & Coptisine & $\begin{array}{l}\text { Donepezil (positive } \\
\text { control 1) }\end{array}$ & $\begin{array}{l}\text { Galantamine (positive } \\
\text { control 2) }\end{array}$ & $\begin{array}{l}\text { Remarks (Best } \\
\text { performers) }\end{array}$ \\
\hline $\begin{array}{l}\text { Molecular docking } \\
\text { study }\end{array}$ & Good & Good & Good & Excellent & Good & Poor & Coptisine \\
\hline $\begin{array}{l}\text { Druglikeness } \\
\text { properties }\end{array}$ & Excellent & Excellent & Excellent & Excellent & Excellent & Excellent & All \\
\hline Absorption & Excellent & Excellent & Excellent & Poor & Good & Poor & $\begin{array}{l}\text { Bellidifolin, naringenin, } \\
\text { apigenin }\end{array}$ \\
\hline Distribution & Excellent & Excellent & Poor & Poor & Excellent & Good & Bellidifolin, naringenin \\
\hline Metabolism & Excellent & Poor & Good & Good & Good & Excellent & Bellidifolin \\
\hline Excretion & Good & Good & Good & Excellent & Excellent & Excellent & Coptisine \\
\hline Toxicity & Good & Excellent & Good & Excellent & Excellent & Excellent & Naringenin \& apigenin \\
\hline PASS Prediction & Good & Good & Good & Good & Good & Good & All \\
\hline P450 SOM & Good & Excellent & Excellent & Poor & Good & Good & Naringenin, apigenin \\
\hline DFT calculations & Good & Good & Poor & Excellent & Good & Good & Coptisine \\
\hline
\end{tabular}

P450 enzymes can act on. For this reason, all these ligands or compounds might be metabolized well by the body.

Frontier's orbitals study or DFT calculation is an important method to predict the pharmacological properties of small molecules. HOMO and LUMO help to study the chemical reactivity and kinetic stability of the query molecules. The term "HOMO" represents the regions on a small molecule which might donate electrons during the formation of a complex and the term "LUMO" corresponds to the regions on a molecule that might receive electrons from the electron donor. The difference in HOMO and LUMO energy is regarded as gap energy that corresponds to the electronic excitation energy. The molecule that has greater orbital gap energy tends to be energetically more unfavorable to undergo a chemical reaction and vice versa [76, 113-117]. All of the 4 ligands were predicted to have significant gap energy representing their possibility to undergo a chemical reaction. However, among the four best selected ligands, coptisine, with its lowest gap energy, was predicted to have higher probability to undergo a chemical reaction $[25,117]$ (Table 9 and Fig. 3).

Considering all the aspects of the study and comparing the four best selected compounds, it can be concluded that bellidifolin has the highest potentiality to be used as anti-AD drug. From Table 10, it is clear that bellidifolin generated the most sound and satisfactory performance among the four compounds, with no poor performance in any of the analysis. Even compared to the positive controls, donepezil and galantamine, bellidifolin generated very good results in almost all the analyses. Therefore, bellidifolin can be considered as the most suitable compound as a drug for $\mathrm{AD}$ treatment among the compounds considered in this study. However, further investigation could also be conducted on other compounds as they had also shown convincing results in the docking analysis (Table 3). And the authors recommend further in vivo and in vitro experiments to strengthen the findings of this study.

\section{Conclusion}

As Alzheimer's disease (AD) is one of the most rapidly growing dementia type diseases in the world, more and more research studies are being conducted to find out the best possible treatment for this disease. Although several treatments are already available, none of these treatments possesses significant satisfactory results. Plants have been known to contain many beneficial agents that can be used to treat a variety of diseases. In this experiment, 50 anti$\mathrm{AChE}$ phytochemicals were selected to analyze their activities against the acetylcholinesterase (AChE) enzyme, which is a key enzyme responsible for the development of $\mathrm{AD}$, by exploiting numerous approaches used in computer-aided drug design. Upon continuous computational experimentation, bellidifolin, naringenin, apigenin, and coptisine were predicted to be the best inhibitors of AChE. Then, their drug potentiality was checked in different post-screening studies where they were also predicted to show quite similar and sound performance, although in some aspects, their performances were not up to the mark. However, more wet-lab based studies must be performed on these 4 agents as well as the other remaining agents to finally confirm their potentiality, safety, and efficacy. 


\section{Supplementary Information}

The online version contains supplementary material available at https://doi. org/10.1186/s43042-020-00127-8.

Additional file 1 : Supplementary Table S1. List of different amino acids within the binding pocket of AChE that interact with the four best selected ligands, along with the bond distances and types of the interactions.

\section{Abbreviations}

AD: Alzheimer's disease; APP: Amyloid precursor protein;

AChE: Acetylcholinesterase; ChAT: Choline acetyltransferase; Ac-CoA: Acetyl coenzyme A; Ch: Choline; PASS: Prediction of Activity Spectra for Substances; SOM: Site of metabolism; MM-GBSA: Molecular mechanics - generalized born and surface area; HOMO: Highest occupied molecular orbital; LUMO: Lowest unoccupied molecular orbital; TPSA: Topological polar surface area; BBB: Blood-brain barrier; HERG: Human ether-a-go-go-related gene

\section{Acknowledgements}

The authors are thankful to the Swift Integrity Computational Lab, Dhaka, Bangladesh, a virtual platform of young researchers, for providing the support.

\section{Authors' contributions}

BS supervised and designed the study; SA conducted the molecular docking study; TKR performed the druglikeness properties and ADMET test; SSI performed the PASS prediction and DFT calculations; YA wrote the manuscript; MAU edited the manuscript. The authors have read and approved the manuscript.

\section{Funding}

No funding was received for conducting the study.

\section{Availability of data and materials}

The tools used in this study are available on the Internet.

\section{Ethics approval and consent to participate}

Not applicable.

\section{Consent for publication}

Not applicable.

\section{Competing interests}

The authors declare that they have no conflict of interest among themselves.

\section{Author details}

${ }^{1}$ Department of Biotechnology and Genetic Engineering, Faculty of Biological Sciences, Jahangirnagar University, Dhaka, Bangladesh. ${ }^{2}$ Department of Genetic Engineering and Biotechnology, School of Life Sciences, Shahjalal University of Science and Technology, Sylhet, Bangladesh.

Received: 10 September 2020 Accepted: 21 December 2020 Published online: 15 February 2021

\section{References}

1. Suh WH, Suslick KS, Suh YH (2005) Therapeutic agents for Alzheimer's disease. Curr Med Chem -Central Nervous Syst Agents 5:259-269. https:// doi.org/10.2174/156801505774913035

2. Ferri $C P$, Prince $M$, Brayne $C$, Brodaty $H$, Fratiglioni L, Ganguli M, Hall K, Hasegawa K, Hendrie H, Huang Y, Jorm A (2005) Global prevalence of dementia: a Delphi consensus study. Lancet 366:2112-2117. https://doi.org/ 10.1016/s0140-6736(05)67889-0

3. Merriam AE, Aronson MK, Gaston P, Wey SL, Katz I (1988) The psychiatric symptoms of Alzheimer's disease. J Am Geriatr Soc 36:7-22. https://doi.org/ 10.1111/j.1532-5415.1988.tb03427.x

4. Nordberg A, Svensson AL (1998) Cholinesterase inhibitors in the treatment of Alzheimer's disease. Drug Saf 19:465-480. https://doi.org/10.2165/ 00002018-199819060-00004

5. Hardy JA, Higgins GA (1992) Alzheimer's disease: the amyloid cascade hypothesis. Science 256:184-186. https://doi.org/10.1126/science.1566067
6. Markesbery WR (1997) Oxidative stress hypothesis in Alzheimer's disease. Free Radic Biol Med 23:134-147. https://doi.org/10.1016/s08915849(96)00629-6

7. Francis PT, Palmer AM, Snape M, Wilcock GK (1999) The cholinergic hypothesis of Alzheimer's disease: a review of progress. J Neurol Neurosurg Psychiatry 66:137-147. https://doi.org/10.1136/jnnp.66.2.137

8. Huang LK, Chao SP, Hu CJ (2020 Dec) Clinical trials of new drugs for Alzheimer disease. J Biomed Sci 27(1):1-3. https://doi.org/10.1186/s12929-019-0609-7

9. https://alzheimersnewstoday.com/experimental-treatments-for-alzheimersdisease-treatments-that-target-beta-amyloid-protein/?cn-reloaded=1. Accessed Jan 2020.

10. Padurariu M, Ciobica A, Lefter R, Lacramioara Serban I, Stefanescu C, Chirita $R$ (2013) The oxidative stress hypothesis in Alzheimer's disease. Psychiatr Danub 25(4):0-409

11. Persson T, Popescu BO, Cedazo-Minguez A (2014) Oxidative stress in Alzheimer's disease: why did antioxidant therapy fail? Oxid Med Cell Longev 2014. https://doi.org/10.1155/2014/427318

12. Teixeira JP, de Castro AA, Soares FV, da Cunha EF, Ramalho TC (2019) Future therapeutic perspectives into the Alzheimer's disease targeting the oxidative stress hypothesis. Molecules. 24(23):4410. https://doi.org/10.3390/ molecules 24234410

13. Terry AV, Buccafusco JJ (2003) The cholinergic hypothesis of age and Alzheimer's disease-related cognitive deficits: recent challenges and their implications for novel drug development. J Pharmacol Exp Ther 306:821827. https://doi.org/10.1124/jpet.102.041616

14. Talesa VN (2001) Acetylcholinesterase in Alzheimer's disease. Mech Ageing Dev 122:1961-1969. https://doi.org/10.1016/s0047-6374(01)00309-8

15. Viegas J, Bolzani VD, Barreiro EJ, Manssour Fraga CA (2005) New antiAlzheimer drugs from biodiversity: the role of the natural acetyl cholinesterase inhibitors. Mini Rev Med Chem 5:915-926. https://doi.org/10. 2174/138955705774329546

16. Bohnen NI, Kaufer DI, Hendrickson R, Ivanco LS, Lopresti B, Davis JG, Constantine G, Mathis CA, Moore RY, DeKosky ST (2005) Cognitive correlates of alterations in acetylcholinesterase in Alzheimer's disease. Neurosci Lett 380:127-132. https://doi.org/10.1016/j.neulet.2005.01.031

17. Hasselmo ME, Bower JM (1993) Acetylcholine and memory. Trends Neurosci 16:218-222. https://doi.org/10.1016/0166-2236(93)90159-j.

18. McGleenon BM, Dynan KB, Passmore AP (1999) Acetylcholinesterase inhibitors in Alzheimer's disease. Br J Clin Pharmacol 48:471. https://doi.org/ 10.1046/j.1365-2125.1999.00026.x

19. Tayeb HO, Yang HD, Price BH, Tarazi Fl (2012) Pharmacotherapies for Alzheimer's disease: beyond cholinesterase inhibitors. Pharmacol Ther 134(1):8-25. https://doi.org/10.1016/j.pharmthera.2011.12.002

20. Farlow M, Veloso F, Moline M, Yardley J, Brand-Schieber E, Bibbiani F, Zou H, Hsu T, Satlin A (2011) Safety and tolerability of donepezil $23 \mathrm{mg}$ in moderate to severe Alzheimer's disease. BMC Neurol 11(1):57. https://doi. org/10.1186/1471-2377-11-57

21. Winblad B, Grossberg G, Frölich L, Farlow M, Zechner S, Nagel J, Lane R (2007) IDEAL: a 6-month, double-blind, placebo-controlled study of the first skin patch for Alzheimer disease. Neurology 69(4 suppl 1):S14-S22. https:// doi.org/10.1212/01.wnl.0000281847.17519.e0

22. Bartolucci C, Perola E, Pilger C, Fels G, Lamba D (2001) Three-dimensional structure of a complex of galanthamine (Nivalin ${ }^{\circledR}$ ) with acetylcholinesterase from Torpedo californica: implications for the design of new anti-Alzheimer drugs. Proteins: Structure Function Bioinform 42(2):182-191. https://doi.org/ 10.1002/1097-0134(20010201)42:2<182::aid-prot50>3.0.co;2-1

23. Pilger C, Bartolucci C, Lamba D, Tropsha A, Fels G (2001) Accurate prediction of the bound conformation of galanthamine in the active site of Torpedo californica acetylcholinesterase using molecular docking. J Mol Graph Model 19(3-4):288-296. https://doi.org/10.1016/s1093-3263(00)00056-5

24. Meng XY, Zhang HX, Mezei M, Cui M (2011) Molecular docking: a powerful approach for structure-based drug discovery. Curr Comput Aided Drug Des 7(2):146-157. https://doi.org/10.2174/157340911795677602

25. Sarkar B, Ullah MA, Islam SS, Rahman MH, Araf Y (2020) Analysis of plantderived phytochemicals as anti-cancer agents targeting cyclin dependent kinase-2, human topoisomerase lla and vascular endothelial growth factor receptor-2. J Recept Signal Transduct:1-7. https://doi.org/10.1080/10799893. 2020.1805628

26. Dhananjayan K, Sumathy A, Palanisamy S (2013) Molecular docking studies and in-vitro acetylcholinesterase inhibition by terpenoids and flavonoids. Asian J Res Chem 6(11):1011-1017 
27. Kitphati W, Wattanakamolkul K, Lomarat P, Phanthong P, Anantachoke N, Nukoolkarn V, Thirapanmethee K, Bunyapraphatsara N (2012) Anticholinesterase of essential oils and their constituents from Thai medicinal plants on purified and cellular enzymes

28. Nag G, Das S, Das S, Mandal S, De B (2015) Antioxidant, antiacetylcholinesterase and anti-glycosidase properties of three species of Swertia, their xanthones and amarogentin: a comparative study. Pharm J 7(2). https://doi.org/10.5530/pj.2015.2.6

29. Cahlíková L, Opletal L, Kurfürst M, Macáková K, Kulhánková A, Hošt'álková A (2010) Acetylcholinesterase and butyrylcholinesterase inhibitory compounds from Chelidonium majus (Papaveraceae). Nat Prod Commun 5(11): 1934578X1000501110. https://doi.org/10.1177/1934578x1000501110

30. Olennikov DN, Kashchenko NI, Chirikova NK, Akobirshoeva A, Zilfikarov IN, Vennos C (2017) Isorhamnetin and quercetin derivatives as antiacetylcholinesterase principles of marigold (Calendula officinalis) flowers and preparations. Int J Mol Sci 18(8):1685. https://doi.org/10.3390/ ijms18081685

31. Hlila MB, Mosbah H, Mssada K, Jannet HB, Aouni M, Selmi B (2015) Acetylcholinesterase inhibitory and antioxidant properties of roots extracts from the Tunisian Scabiosa arenaria Forssk. Ind Crop Prod 67:62-69. https:// doi.org/10.1016/j.indcrop.2015.01.009

32. Urbain A, Marston A, Hostettmann K (2005) Coumarins from Peucedanum ostruthium as inhibitors of acetylcholinesterase. Pharm Biol 43(8):647-650. https://doi.org/10.1080/13880200500382720

33. Kim DK (2002) Inhibitory effect of corynoline isolated from the aerial parts of corydalis incisa on the acetylcholinesterase. Arch Pharm Res 25(6):817. https://doi.org/10.1007/bf02976997

34. Andrade MT, Lima JA, Pinto AC, Rezende CM, Carvalho MP, Epifanio RA (2005) Indole alkaloids from Tabernaemontana australis (Müell. Arg) Miers that inhibit acetylcholinesterase enzyme. Bioorg Med Chem 13(12):40924095. https://doi.org/10.1016/j.bmc.2005.03.045

35. Wangchuk P, Keller PA, Pyne SG, Sastraruji T, Taweechotipatr M, Rattanajak R, Tonsomboon A, Kamchonwongpaisan S (2012) Phytochemical and biological activity. https://doi.org/10.1177/1934578×1200700507

36. Farag MA, Ezzat SM, Salama MM, Tadros MG, Serya RA (2016) Antiacetylcholinesterase activity of essential oils and their major constituents from four Ocimum species. Z Naturforsch C 71(11-12):393-402. https://doi. org/10.1515/znc-2016-0030

37. Heo HJ, Kim MJ, Lee JM, Choi SJ, Cho HY, Hong B, Kim HK, Kim E, Shin DH (2004) Naringenin from Citrus junos has an inhibitory effect on acetylcholinesterase and a mitigating effect on amnesia. Dement Geriatr Cogn Disord 17(3):151-157. https://doi.org/10.1159/000076349

38. Tundis R, Bonesi M, Menichini F, Loizzo MR, Conforti F, Statti G, Pirisi FM, Menichini F (2012) Antioxidant and anti-cholinesterase activity of Globularia meridionalis extracts and isolated constituents. Nat Prod Commun 7(8): 1934578X1200700814. https://doi.org/10.1177/1934578×1200700814

39. Askin H, Yildiz M, Ayar A (2017) Effects of thymol and carvacrol on acetylcholinesterase from drosophila melanogaster. Acta Physica Polonica A 132(3):720-722. https://doi.org/10.12693/aphyspola.132.720

40. Jukic M, Politeo O, Maksimovic M, Milos M, Milos M (2007) In vitro acetylcholinesterase inhibitory properties of thymol, carvacrol and their derivatives thymoquinone and thymohydroquinone. Phytother Res 21(3): 259-261. https://doi.org/10.1002/ptr.2063

41. Kaufmann D, Dogra AK, Wink M (2011) Myrtenal inhibits acetylcholinesterase, a known Alzheimer target. J Pharm Pharmacol 63(10): 1368-1371. https://doi.org/10.1111/j.2042-7158.2011.01344.x

42. Ndhlala AR, Aremu AO, Moyo M, Amoo SO, Van Staden J (2012) Acetylcholineterase inhibitors from plant sources: friends or foes. Cholinesterase: Production, Uses Health Effects:67-98. https://doi.org/10. 1016/b978-0-12-405927-6.00016-3

43. Matochko WL, James A, Lam CW, Kozera DJ, Ata A, Gengan RM (2010) Triterpenoidal alkaloids from Buxus natalensis and their acetylcholinesterase inhibitory activity. J Nat Prod 73(11):1858-1862. https://doi.org/10.1021/ np100494u

44. Yang ZD, Zhang DB, Ren J, Yang MJ (2012) Skimmianine, a furoquinoline alkaloid from Zanthoxylum nitidum as a potential acetylcholinesterase inhibitor. Med Chem Res 21(6):722-725. https://doi.org/10.1007/s00044-011-9581-9

45. Cabral RS, Sartori MC, Cordeiro I, Queiroga CL, Eberlin MN, Lago JH, Moreno PR, Young M (2012) Anticholinesterase activity evaluation of alkaloids and coumarin from stems of Conchocarpus fontanesianus. Rev Bras Farm 22(2): 374-380. https://doi.org/10.1590/s0102-695×2011005000219
46. Adhami HR, Farsam H, Krenn L (2011) Screening of medicinal plants from Iranian traditional medicine for acetylcholinesterase inhibition. Phytother Res 25(8):1148-1152. https://doi.org/10.1002/ptr.3409

47. Wszelaki N, Kuciun A, Kiss A (2010) Screening of traditional European herbal medicines for acetylcholinesterase and butyrylcholinesterase inhibitory activity. Acta Pharm 60(1):119-128. https://doi.org/10.2478/ v10007-010-0006-y

48. Howes MJ, Houghton PJ (2009) Acetylcholinesterase inhibitors of natural origin. Int J Biomed Pharm Sci 3(SI1):67-86

49. Phoopichayanun C (2007) Acetylcholinesterase inhibitors from roots of Feroniella lucida (Doctoral dissertation)

50. Dohi S, Terasaki M, Makino M (2009) Acetylcholinesterase inhibitory activity and chemical composition of commercial essential oils. J Agric Food Chem 57(10):4313-4318. https://doi.org/10.1021/jf804013j

51. Balkis A, Tran K, Lee YZ, Ng K (2015) Screening flavonoids for inhibition of acetylcholinesterase identified baicalein as the most potent inhibitor. Int J Biol 7(9):26. https://doi.org/10.5539/jas.v7n9p26

52. Antikolinesteraz AHTP, Bitkileri BKOLF (2014) Lamiaceae family plants as a potential anticholinesterase source in the treatment of Alzheimer's disease. Bezmialem Sci 1:1-25

53. Mollataghi A, Coudiere E, Hadi AHA, Mukhtar MR, Awang K, Litaudon M, Ata A (2012) Anti-acetylcholinesterase, anti-a-glucosidase, anti-leishmanial and anti-fungal activities of chemical constituents of Beilschmiedia species. Fitoterapia 83(2):298-302. https://doi.org/10.1016/j.fitote.2011.11.009

54. Kaufmann D, Kaur Dogra A, Tahrani A, Herrmann F, Wink M (2016) Extracts from traditional Chinese medicinal plants inhibit acetylcholinesterase, a known Alzheimer's disease target. Molecules 21(9):1161. https://doi.org/10. 3390/molecules21091161

55. Vladimir-Knežević S, Blažeković B, Kindl M, Vladić J, Lower-Nedza AD, Brantner AH (2014) Acetylcholinesterase inhibitory, antioxidant and phytochemical properties of selected medicinal plants of the Lamiaceae family. Molecules 19(1):767-782. https://doi.org/10.3390/molecules19010767

56. Falé $\mathrm{PL}$, Ferreira $\mathrm{C}$, Rodrigues $\mathrm{AM}$, Cleto $\mathrm{P}$, Madeira PA, Florêncio MH, Frazão FN, Serralheiro ML (2013) Antioxidant and anti-acetylcholinesterase activity of commercially available medicinal infusions after in vitro gastrointestinal digestion. J Med Plant Res 7(20):1370-1378. https://doi.org/10.5897/jmpr13. 4438

57. Min BS, Cuong TD, Lee JS, Shin BS, Woo MH, Hung TM (2010) Cholinesterase inhibitors from Cleistocalyx operculatus buds. Arch Pharm Res 33(10):1665-1670. https://doi.org/10.1007/s12272-010-1016-5

58. Ogura H, Kosasa T, Kuriya Y, Yamanishi Y (2000) Comparison of inhibitory activities of donepezil and other cholinesterase inhibitors on acetylcholinesterase and butyrylcholinesterase in vitro. Methods Find Exp Clin Pharmacol 22(8):609-614. https://doi.org/10.1358/mf.2000.22.8.701373

59. Cummings JL, Geldmacher D, Farlow M, Sabbagh M, Christensen D, Betz P, Donepezil 23 mg Expert Working Group (2013) High-dose donepezil (23 $\mathrm{mg} /$ day) for the treatment of moderate and severe Alzheimer's disease: drug profile and clinical guidelines. CNS Neurosci Ther 19:294-301. https:// doi.org/10.1111/cns.12076

60. Schrödinger Release 2018-4: protein preparation wizard; Epik, Schrödinger, LLC, New York, NY, 2016; Impact, Schrödinger, LLC, New York, NY, 2016; Prime, Schrödinger, LLC, New York, NY, 2018.

61. Schrödinger Release 2018-4: Prime, Schrödinger, LLC, New York, 2018.

62. Schrödinger Release 2018-4: LigPrep, Schrödinger, LLC, New York, 2018.

63. Schrödinger Release 2018-4: Epik, Schrödinger, LLC, New York, 2018.

64. Schrödinger Release 2018-4: Glide, Schrödinger, LLC, New York, 2018.

65. Dash R, Hosen SZ, Karim MR, Kabir MS, Hossain MM, Junaid M, Islam A, Paul A, Khan MA (2015) In silico analysis of indole-3-carbinol and its metabolite DIM as EGFR tyrosine kinase inhibitors in platinum resistant ovarian cancer vis a vis ADME/T property analysis. J App Pharm Sci 5(11):073-078. https:// doi.org/10.7324/japs.2015.501112

66. Visualizer DS (2017) Release 4.1. Accelrys Inc., San Diego

67. Daina A, Michielin O, Zoete V (2017) SwissADME: a free web tool to evaluate pharmacokinetics, drug-likeness and medicinal chemistry friendliness of small molecules. Sci Rep 7:42717. https://doi.org/10.1038/ srep42717

68. Cheng F, Li W, Zhou Y, Shen J, Wu Z, Liu G, Lee P, W.; Tang, Y. (2012) admetSAR: a comprehensive source and free tool for assessment of chemical ADMET properties. https://doi.org/10.1021/ci300367a

69. Dong J, Wang NN, Yao ZJ, Zhang L, Cheng Y, Ouyang D, Lu AP, Cao DS (2018) ADMETlab: a platform for systematic ADMET evaluation based on a 
comprehensively collected ADMET database. J Chem 10(1):29. DOI. https:// doi.org/10.1186/s13321-018-0283-x

70. Filimonov DA, Lagunin AA, Gloriozova TA, Rudik AV, Druzhilovskii DS, Pogodin PV, Poroikov W (2014) Prediction of the biological activity spectra of organic compounds using the PASS online web resource. Chem Heterocycl Compd 50(3):444-457. https://doi.org/10.1007/s10593-014-1496-1

71. Geronikaki A, Poroikov V, Hadjipavlou-Litina D, Filimonov D, Lagunin A, Mgonzo R (1999) Computer aided predicting the biological activity spectra and experimental testing of new thiazole derivatives. Quant Struct-act Rel 18(1):16-25. https://doi.org/10.1002/(sici)1521-3838(199901)18:1<16::aidqsar16>3.0.co;2-o

72. Zaretzki J, Bergeron C, Huang TW, Rydberg P, Swamidass SJ, Breneman CM (2012) RS-WebPredictor: a server for predicting CYP-mediated sites of metabolism on drug-like molecules. Bioinformatics 29(4):497-498. https:// doi.org/10.1093/bioinformatics/bts705

73. Drwal MN, Banerjee P, Dunkel M, Wettig MR, Preissner R (2014) ProTox: a web server for the in silico prediction of rodent oral toxicity. Nucleic Acids Res 42(W1):W53-W58. https://doi.org/10.1093/nar/gku401

74. Schrödinger Release 2018-4: Jaguar, Schrödinger, LLC, New York, 2018

75. Lee C, Yang W, Parr RG (1988) Development of the Colle-Salvetti correlation-energy formula into a functional of the electron density. Phys Rev B 37(2):785. https://doi.org/10.1103/physrevb.37.785

76. Becke AD (1988) Density-functional exchange-energy approximation with correct asymptotic behavior. Phys Rev A 38(6):3098. https://doi.org/10.1103/ physreva.38.3098

77. Pearson RG (1986) Absolute electronegativity and hardness correlated with molecular orbital theory. P Natl Acad Sci 83(22):8440-8441. https://doi.org/ 10.1073/pnas.83.22.8440

78. Parr RG, Yang W (1989) Density-functional theory of atoms and molecules, vol. 16 of International series of monographs on chemistry. Oxford University Press, New York

79. Yuriev E, Ramsland PA (2013) Latest developments in molecular docking: 20102011 in review. J Mol Recognit 26(5):215-239. https://doi.org/10.1002/jmr.2266

80. Zhang X, Perez-Sanchez H, C-Lightstone F (2017) A comprehensive docking and MM/GBSA rescoring study of ligand recognition upon binding antithrombin. Curr Top Med Chem 4v(14):1631-1639. https://doi.org/10. 2174/1568026616666161117112604

81. Sherman W, Day T, Jacobson MP, Friesner RA, Farid R (2006) Novel procedure for modeling ligand/receptor induced fit effects. J Med Chem 49(2):534-553. DOl. https://doi.org/10.1021/jm050540c

82. Aamir M, Singh VK, Dubey MK, Meena M, Kashyap SP, Katari SK, Upadhyay RS, Singh S (2018) In silico prediction, characterization, molecular docking and dynamic studies on fungal SDRs as novel targets for searching potential fungicides against fusarium wilt in tomato. Front Pharmacol 9 : 1038. https://doi.org/10.3389/fphar.2018.01038

83. Friesner RA, Murphy RB, Repasky MP, Frye LL, Greenwood JR, Halgren TA, Sanschagrin PC, Mainz DT (2006) Extra precision glide: docking and scoring incorporating a model of hydrophobic enclosure for protein-ligand complexes. J Med Chem 49(21):6177-6196. https://doi.org/10.1021/jm0512560

84. Priyadarshini V, Pradhan D, Munikumar M, Swargam S, Umamaheswari A, Rajasekhar D (2014) Genome-based approaches to develop epitope-driven subunit vaccines against pathogens of infective endocarditis. J Biomol Struct Dyn 32(6):876-889. https://doi.org/10.1080/07391102.2013.795871

85. Gohlke H, Hendlich M, Klebe G (2000) Knowledge-based scoring function to predict protein-ligand interactions. J Mol Biol 295(2):337-356. https://doi. org/10.1006/jmbi.1999.3371

86. Shoichet BK, McGovern SL, Wei B, Irwin JJ (2002) Lead discovery using molecular docking. Curr Opin Chem Biol 6(4):439-446. https://doi.org/10 1016/s1367-5931(02)00339-3

87. Dvir H, Silman I, Harel M, Rosenberry TL, Sussman JL (2010) Acetylcholinesterase: from 3D structure to function. Chem Biol Interact 187(1-3):10-22. DOI. https://doi.org/10.1016/j.cbi.2010.01.042

88. Klebe G (2015) Protein-ligand interactions as the basis for drug action. In: Multifaceted Roles of Crystallography in Modern Drug Discovery. Springer, Dordrecht, pp 83-92. https://doi.org/10.1007/978-94-017-9719-1_7

89. Lipinski CA (2004) Lead-and drug-like compounds: the rule-of-five revolution Drug Discov Today Technol 1:337-341. https://doi.org/10.1016/j.ddtec.2004.11.007

90. Pollastri MP (2010) Overview on the rule of five. Curr Protoc Pharmacol 49: 9-12. https://doi.org/10.1002/0471141755.ph0912s49

91. Ullah A, Prottoy NI, Araf Y, Hossain S, Sarkar B, Saha A (2019) Molecular docking and pharmacological property analysis of phytochemicals from
Clitoria ternatea as potent inhibitors of cell cycle checkpoint proteins in the cyclin/CDK pathway in cancer cells. Comput Mol Biosci 9(03):81. DOI. https://doi.org/10.4236/cmb.2019.93007

92. Sarkar B, Islam SS, Ullah MA, Hossain S, Prottoy MN, Araf Y, Taniya MA (2019) Computational assessment and pharmacological property breakdown of eight patented and candidate drugs against four intended targets in Alzheimer's disease. Adv Biosci Biotechnol 10(11):405. https://doi.org/10. 4236/abb.2019.1011030

93. Li AP (2001) Screening for human ADME/Tox drug properties in drug discovery. Drug Discov Today 6(7):357-366. https://doi.org/10.1016/s13596446(01)01712-3

94. Guengerich FP (1999) Cytochrome P-450 3A4: regulation and role in drug metabolism. Annu Rev Pharmacol Toxicol 39(1):1-17. https://doi.org/10. 1146/annurev.pharmtox.39.1.1

95. Glue P, Clement RP (1999) Cytochrome P450 enzymes and drug metabolism—basic concepts and methods of assessment. Cell Mol Neurobiol 19(3):309-323. https://doi.org/10.1023/a:1006993631057

96. Dixit B (2017) A review on the effects of CMPF binding with human serum albumin. Bioinform Rev 3(9):9-18

97. Radchenko EV, Dyabina AS, Palyulin VA, Zefirov NS (2016) Prediction of human intestinal absorption of drug compounds. Russ Chem Bull 65(2):576580. https://doi.org/10.1007/s11172-016-1340-0

98. Wessel MD, Jurs PC, Tolan JW, Muskal SM (1998) Prediction of human intestinal absorption of drug compounds from molecular structure. J Chem Inf Comput Sci 38(4):726-735. https://doi.org/10.1021/ci980029a

99. Basant N, Gupta S, Singh KP (2016) Predicting human intestinal absorption of diverse chemicals using ensemble learning based QSAR modeling approaches. Comput Biol Chem 61:178-196. https://doi.org/10.1016/j. compbiolchem.2016.01.005

100. Swierczewska M, Lee KC, Lee S (2015) What is the future of PEGylated therapies? https://doi.org/10.1517/14728214.2015.1113254

101. Smalling RW (1996) Molecular biology of plasminogen activators: what are the clinical implications of drug design? Am J Cardiol 78(12):2-7. https://doi. org/10.1016/s0002-9149(96)00736-9

102. Sahin S, Benet LZ (2008) The operational multiple dosing half-life: a key to defining drug accumulation in patients and to designing extended release dosage forms. Pharm Res 25(12):2869-2877. https://doi.org/10.1007/s11095008-9787-9

103. Sanguinetti MC, Jiang C, Curran ME, Keating MT (1995) A mechanistic link between an inherited and an acquird cardiac arrthytmia: HERG encodes the IKr potassium channel. Cell 81(2):299-307. https://doi.org/10.1016/00928674(95) $90340-2$

104. Aronov AM (2005) Predictive in silico modeling for hERG channel blockers. Drug Discov Today 10(2):149-155. https://doi.org/10.1016/s13596446(04)03278-7

105. Cheng A, Dixon SL (2003) In silico models for the prediction of dosedependent human hepatotoxicity. J Comput Aid Mol Des 17(12):811-823. https://doi.org/10.1023/b:jcam.0000021834.50768.c6

106. Xu JJ, Diaz D, O'Brien PJ (2004) Applications of cytotoxicity assays and pre-lethal mechanistic assays for assessment of human hepatotoxicity potential. Chem Biol Interact 150(1):115-128. https://doi.org/10.1016/j. cbi.2004.09.011

107. Mortelmans K, Zeiger E (2000) The Ames Salmonella/microsome mutagenicity assay. Mutat Res-Fund Mol M 455(1-2):29-60. https://doi.org/ 10.1016/s0027-5107(00)00064-6

108. Holt, M P, ; Ju, C. Mechanisms of drug-induced liver injury. AAPS J. 2006, 8(1), E48-E54. DOl: https://doi.org/10.1208/aapsj080106

109. Lagunin A, Stepanchikova A, Filimonov D, Poroikov V (2000) PASS: prediction of activity spectra for biologically active substances. Bioinformatics 16(8):747-748. https://doi.org/10.1093/bioinformatics/16.8.747

110. United Nations. Economic Commission for Europe. Secretariat, 2005. Globally harmonized system of classification and labelling of chemicals (GHS). United Nations Publications. https://unece.org/ghs-rev1-2005. Accessed 3 Dec 2020.

111. Tyzack JD, Mussa HY, Williamson MJ, Kirchmair J, Glen RC (2014) Cytochrome P450 site of metabolism prediction from 2D topological fingerprints using GPU accelerated probabilistic classifiers. J scinemrofnimehC 6(1):29. https://doi.org/10.1186/1758-2946-6-29

112. Danielson PB (2002) The cytochrome P450 superfamily: biochemistry, evolution and drug metabolism in humans. Curr Drug Metab 3(6):561-597. https://doi.org/10.2174/1389200023337054 
113. Matysiak J (2007) Evaluation of electronic, lipophilic and membrane affinity effects on antiproliferative activity of 5-substituted-2-(2, 4-dihydroxypheny)1, 3, 4-thiadiazoles against various human cancer cells. Eur J Med Chem 42(7):940-947. https://doi.org/10.1016/.ejmech.2006.12.033

114. Zhan CG, Nichols JA, Dixon DA (2003) Ionization potential, electron affinity, electronegativity, hardness, and electron excitation energy: molecular properties from density functional theory orbital energies. J Phys Chem A 107(20):4184-4195. DOI. https://doi.org/10.1021/jp0225774

115. Hoque MM, Halim MA, Sarwar MG, Khan MW (2015) Palladium-catalyzed cyclization of 2-alkynyl-N-ethanoyl anilines to indoles: synthesis, structural, spectroscopic, and mechanistic study. J Phys Org Chem 28(12):732-742. https://doi.org/10.1002/poc.3477

116. Ayers PW, Parr RG, Pearson RG (2006) Elucidating the hard/soft acid/base principle: a perspective based on half-reactions. J Chem Phys 124(19): 194107. https://doi.org/10.1063/1.2196882

117. Ullah MA, Johora FT, Sarkar B, Araf Y, Rahman MH (2020) Curcumin analogs as the inhibitors of TLR4 pathway in inflammation and their drug like potentialities: a computer-based study. J Recept Signal Transduct:1-5. https://doi.org/10.1080/10799893.2020.1742741

\section{Publisher's Note}

Springer Nature remains neutral with regard to jurisdictional claims in published maps and institutional affiliations.

\section{Submit your manuscript to a SpringerOpen ${ }^{\circ}$ journal and benefit from:}

- Convenient online submission

- Rigorous peer review

- Open access: articles freely available online

- High visibility within the field

- Retaining the copyright to your article

Submit your next manuscript at $\boldsymbol{\nabla}$ springeropen.com 